\title{
Republic of Equatorial Guinea: 2010 Article IV Consultation
}

The following documents have been released and are included in this package:

- $\quad$ The staff report, prepared by a staff team of the IMF, following discussions that ended on March 10, 2010, with the officials of the Republic of Equatorial Guinea on economic developments and policies. Based on information available at the time of these discussions, the staff report was completed on April 8, 2010. The views expressed in the staff report are those of the staff team and do not necessarily reflect the views of the Executive Board of the IMF.

- Debt Sustainability Analysis.

- $\quad$ A Public Information Notice (PIN) summarizing the views of the Executive Board.

The document listed below will be separately released.

Statistical Appendix

The policy of publication of staff reports and other documents allows for the deletion of market-sensitive information.

\author{
Copies of this report are available to the public from \\ International Monetary Fund • Publication Services \\ $70019^{\text {th }}$ Street, N.W. • Washington, D.C. 20431 \\ Telephone: (202) 623-7430 • Telefax: (202) 623-7201 \\ E-mail: publications@imf.org Internet: http://www.imf.org
}

\section{International Monetary Fund Washington, D.C.}




\section{INTERNATIONAL MONETARY FUND}

\section{REPUBLIC OF EQUATORIAL GUINEA}

\section{Staff Report for the 2010 Article IV Consultation}

Prepared by the Staff Representatives for the 2010 Consultation

with the Republic of Equatorial Guinea

Approved by Domenico Fanizza and Dhaneshwar Ghura

April 8, 2010

- Discussions: Held in Malabo, February 24-March 10, 2010 with Mr. Esono Edjo, Minister of Finance and Budget; Mr. Ela Oyana, Minister of Planning, Economic Development and Public Investment; Mr. Ondo Mañe, Presidential Counselor; Mrs. Bindang Obiang, the Banque des Etats de l'Afrique Centrale (BEAC) National Director; other senior government officials; and civil society, the diplomatic community, and technical assistance providers.

- Team: Ms. Baker (head), and Messrs. Milkov and Poplawski-Ribeiro (all AFR). Mr. Ondo Bile, Advisor (OED), participated in the discussions. The mission was assisted by Mr. Cuevas and Ms. Bertel-Mora, IMF-backstopped advisors.

- Exchange Arrangement: Member of the Central African Economic and Monetary Community (CEMAC). The common currency, the CFA franc, is pegged at the fixed exchange rate of CFA franc 656 per euro. CEMAC member countries accepted the obligations of Article VIII in 1996.

- Data: Serious shortcomings that hamper surveillance, hinder policy formulation and impede assessment of progress in achieving MDGs. 


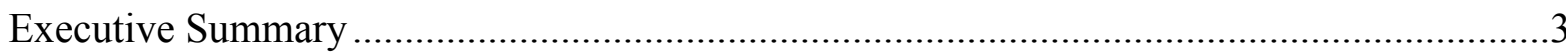

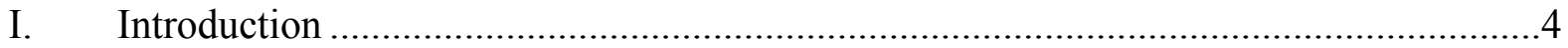

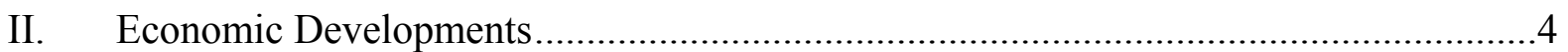

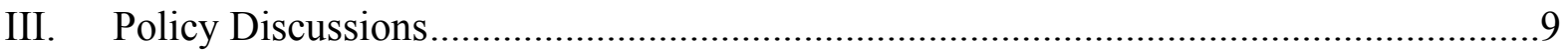

A. Strengthening external stability through sustainable fiscal policy ...................11

B. Public Financial Management: Strong institutions and governance.................13

C. Economic diversification and private sector-led growth ..................................14

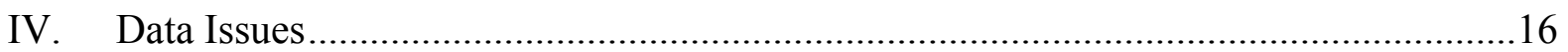

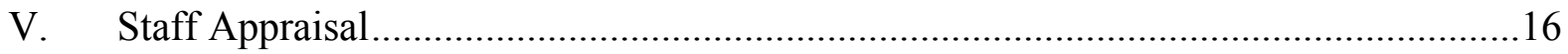

Tables

1. Selected Economic and Financial Indicators, 2006-10

2. Summary of Real Sector Developments, 2006-10 …….........................................19

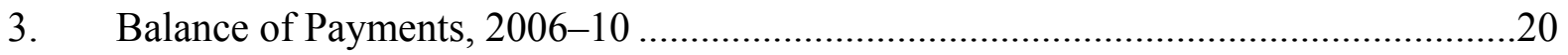

4a. Summary of Central Government Financial Operations, 2006-10 .............................21

4b. Summary of Central Government Financial Operations, 2006-10 ……………...........22

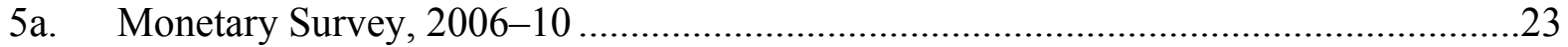

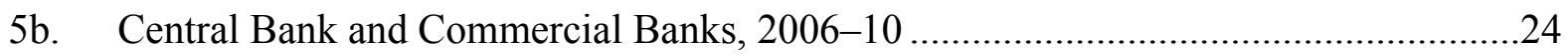

6. Financial Soundness Indicators for the Banking Sector, 2002-09..............................25

7. Selected Medium-Term Economic and Financial Indicators, 2010-15 …....................26

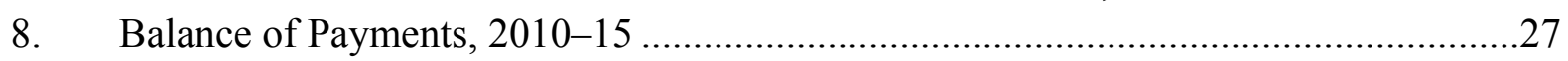

9a. Summary of Central Government Financial Operations, 2010-15 ……………..........28

9b. Summary of Central Government Financial Operations, 2010-15 ..............................29

Figures

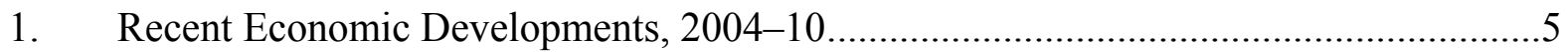

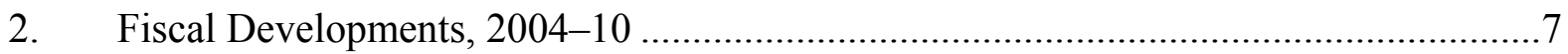

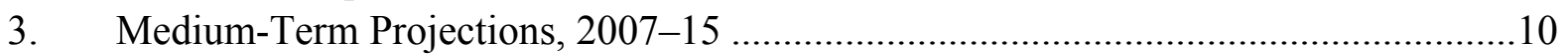

Box

1. National Development Plan 2020: Potential Sources of Growth and Diversification ..15 


\section{EXECUTIVE SUMMARY}

With the economy transitioning to what is projected to be the post-oil period, discussions focused on policy adjustments aimed at achieving fiscal sustainability; raising investment efficiency; improving public financial management; and supporting economic diversification.

\section{Background and outlook}

Oil has brought great wealth and growth to the Equatoguinean economy. However, with crude oil production on the decline and still-large development needs, preparations for the post-oil period should begin. The authorities' ambitious public investment program implies significant government dis-saving over the medium term, to the detriment of external stability. Longer-term prospects hinge on the successful diversification of the economy.

\section{The authorities' policies and views}

- $\quad$ Guided by the National Development Plan 2020, policies aim to build up basic infrastructure in support of improved social welfare and greater diversification.

- $\quad$ There is increasing recognition of the need to increase government savings over the medium term, but spending commitments reduce the scope for near-term adjustment.

- $\quad$ Efforts to strengthen public financial management are being stepped up, through collaboration with the international community.

- $\quad$ Collaboration with banks on financing modalities for SMEs is being discussed, while support for financial sector development at the regional level continues.

- The role of government in economic diversification is that of facilitator. However, in the near term, it may be necessary to fill gaps left by an unwilling private sector.

\section{Staff's recommendations}

- $\quad$ Starting in 2010, steps toward a sustainable fiscal position should be taken to reverse the projected near-depletion of government savings over the medium term. The non-oil primary deficit should be brought down to around 40 percent of non-oil GDP. Such an adjustment is large but feasible, as the envelope covers projects in train with space for new priority spending. Spending rationalization and right-sizing are needed.

- $\quad$ Better public financial management is critical, especially on expenditure control. Efforts to strengthen transparency and governance should continue.

- $\quad$ The exchange rate regime has served the economy well, but unsustainable fiscal policies pose serious risks to external stability. On reserve holdings, the authorities should comply with obligations under CEMAC to support the exchange rate peg.

- Successful economic diversification requires continued action to strengthen human capital and improve the business climate; financial sector development is also key. 


\section{INTRODUCTION}

1. Oil has brought great wealth and growth to the Equatoguinean economy, but challenges remain. Real GDP has increased forty-fold since 1995, and large oil revenues have allowed the government to embark on an ambitious infrastructure investment program while amassing foreign savings. Basic infrastructure is being developed, and although achievements in social areas have been muted, expenditure in this area is programmed to rise. However, with crude oil production on the decline and still-large development needs, preparations for the post-oil period outside of infrastructure should not be delayed. Longterm prospects will depend on the ability to develop a thriving non-oil sector which provides growth and employment opportunities.

2. The discussions focused on policies to safeguard macroeconomic and external stability as oil revenues wane, while at the same time making progress toward achieving the wide-ranging goals set forth in the National Development Plan 2008-20 (NDP).

\section{ECONOMIC DEVELOPMENTS}

\section{Background}

In 2009, performance of Equatorial Guinea's oil-based economy was mixed. Oil prices and production declined, while unprecedented public sector investment buoyed non-oil growth but sent the fiscal deficit soaring. The external position weakened.

3. Economic developments continue to be underpinned by hydrocarbon sector activity and public investment (Figure 1).

- Growth in 2009 was driven mainly by continued strong activity in hydrocarbon derivatives (mostly liquefied natural gas, LNG) and a surge in public investment (construction, utilities, housing), which more than offset the effect of falling crude oil production. ${ }^{1}$ Real GDP is estimated to have expanded by about 5 percent.

- $\quad$ Inflation continued to rise to about $73 / 4$ percent, despite falling global food and oil prices, due to lack of competition in the retail sector, rising public sector wages, and strong domestic demand.

- $\quad$ The external position weakened. The stock of government savings - the relevant proxy for the international investment position - declined moderately, but remained large, propped up in part by renewed foreign borrowing. The current account

\footnotetext{
${ }^{1}$ After peaking in 2008 , crude oil production fell by $11 \frac{1}{2}$ percent in 2009 . Outside of oil production, severe statistical deficiencies call for caution in assessing economic developments.
} 
Figure 1. Equatorial Guinea: Recent Economic Developments, 2004-10

In 2009 growth moderated as robust construction and hydrocarbon derivatives output was offset by declining oil production.

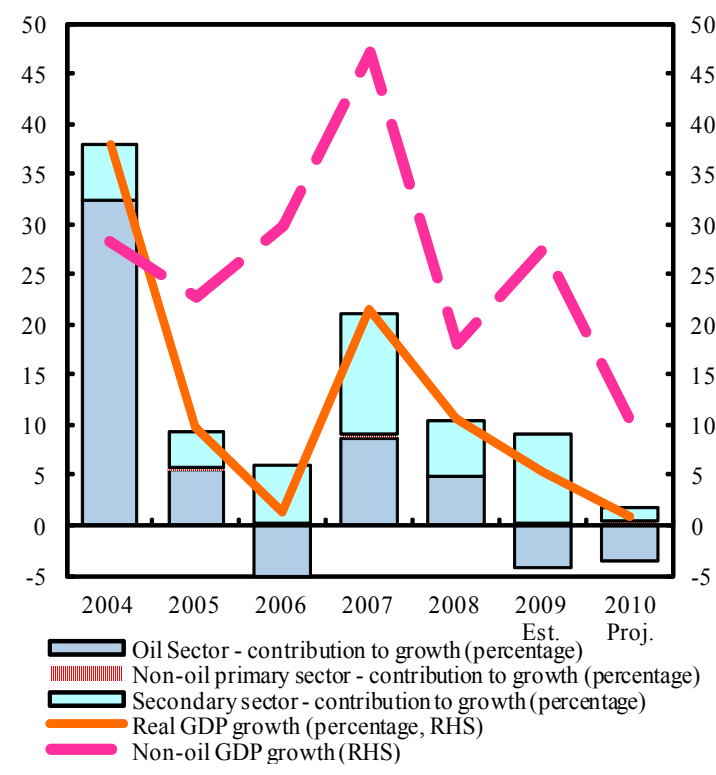

Declining oil prices and lower crude production led to a sharp reduction in the trade surplus, and pushed the current account into deficit..

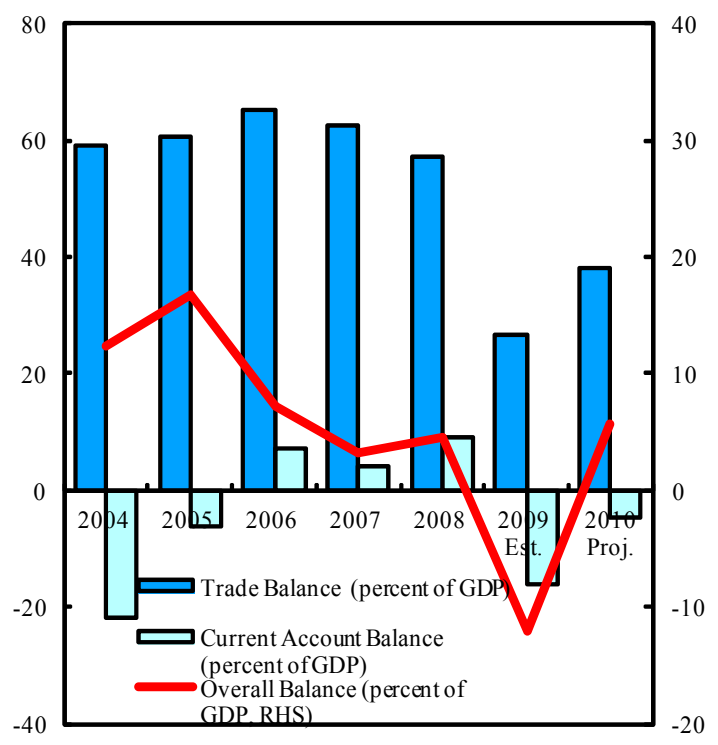

Lack of competition in local goods markets and strong demand pushed inflation higher, but real appreciation was muted by a weakening of the Euro in late 2009.

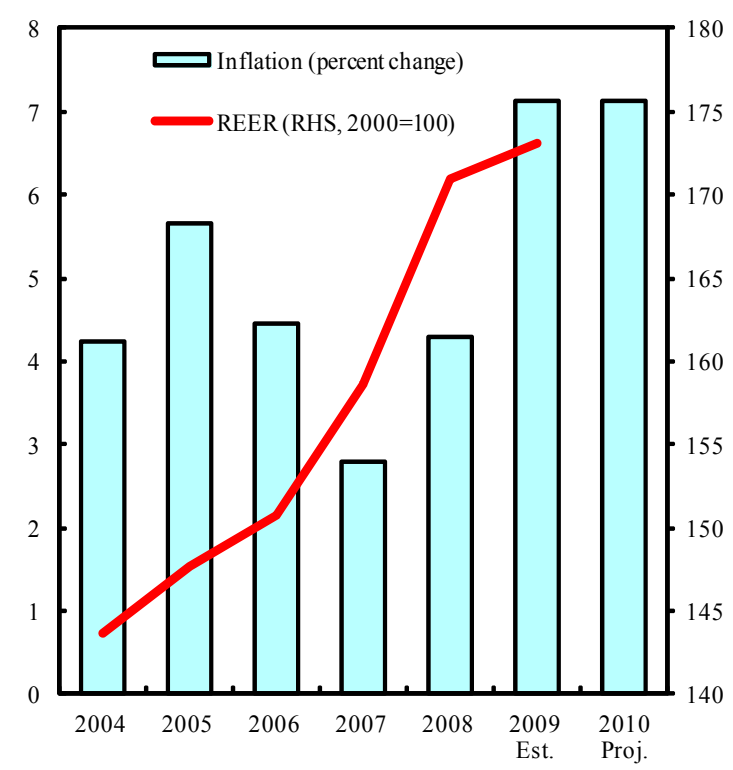

... which was financed by a drawdown in government savings, FDI, and renewed borrowing. The increase in commercial banks depositis in BEAC lifted gross official reserves.

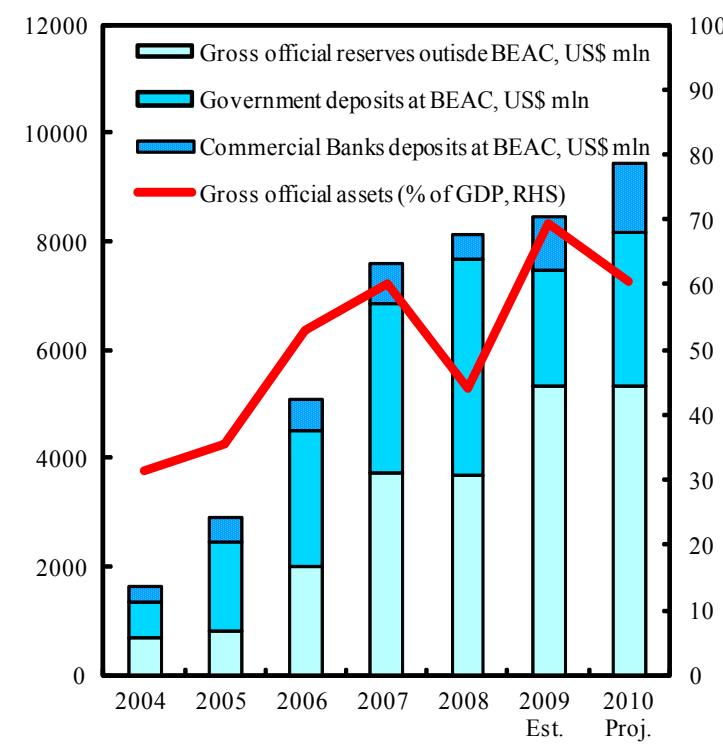

Sources: National authorities, and IMF staff estimates. 
plummeted, with rising hydrocarbon derivatives exports insufficient to offset falling crude production, the plunge in oil prices, and the surge in public investment-related imports. The deficit of about 16 percent of GDP was financed mostly by FDI and public debt.

- $\quad$ The real effective exchange rate appreciated by 4 percent in the 12 months through December 2009 as late-year weakening of the euro to which the CFA franc is pegged mitigated the effect of inflation above that of trading partners.

4. In 2009, over-execution of budgeted capital expenditure led to a substantial deterioration of the fiscal position, while official foreign assets held at the Bank for Central African States (BEAC) declined (Figure 2).

- The overall fiscal balance shifted into a deficit of 8.0 percent of GDP (versus a surplus of 1.7 percent of GDP in the original budget), while the non-oil primary deficit (NOPD) plummeted to over 100 percent of non-oil GDP ( 80 percent of non-oil GDP in the budget). Foreign borrowing and a drawdown of government savings of near equal parts financed the deficit. ${ }^{2}$

- $\quad$ Revenue came in nearly on budget as lower oil royalties were offset by customary over-performance in other areas resulting from conservative budgeting.

- Expenditure surged over the course of the year as oil prices recovered, and the revised budget targets adopted in March were abandoned. Unprecedented spending under the public investment program (PIP) surpassed the original budget by some 25 percent. Current expenditure rose moderately reflecting a slightly higher wage bill, some additional spending on goods and services, and the start of implementation of spending—albeit small—under the Social Needs Fund.

- Notwithstanding the relatively modest decline in government savings, government assets held at BEAC declined by half, with the share held outside the regional central bank rising to over 70 percent (50 percent in 2008). Gross official reserves of BEAC are estimated to have declined by about $\$ 1.5$ billion to $\$ 14.2$ billion at end-2009, broadly reflecting the reduction in Equatorial Guinea's deposits.

\footnotetext{
${ }^{2}$ The authorities drew $\$ 498$ million from a $\$ 2$ billion (nonconcessional) line of credit extended by the Chinese government in late 2006 to help finance infrastructure for electrification and port enlargement. A \$380 million long-term loan on more concessional terms is being made available to finance housing construction.
} 
Figure 2. Equatorial Guinea: Fiscal Developments, 2004-10

Revenues held up despite low oil prices...

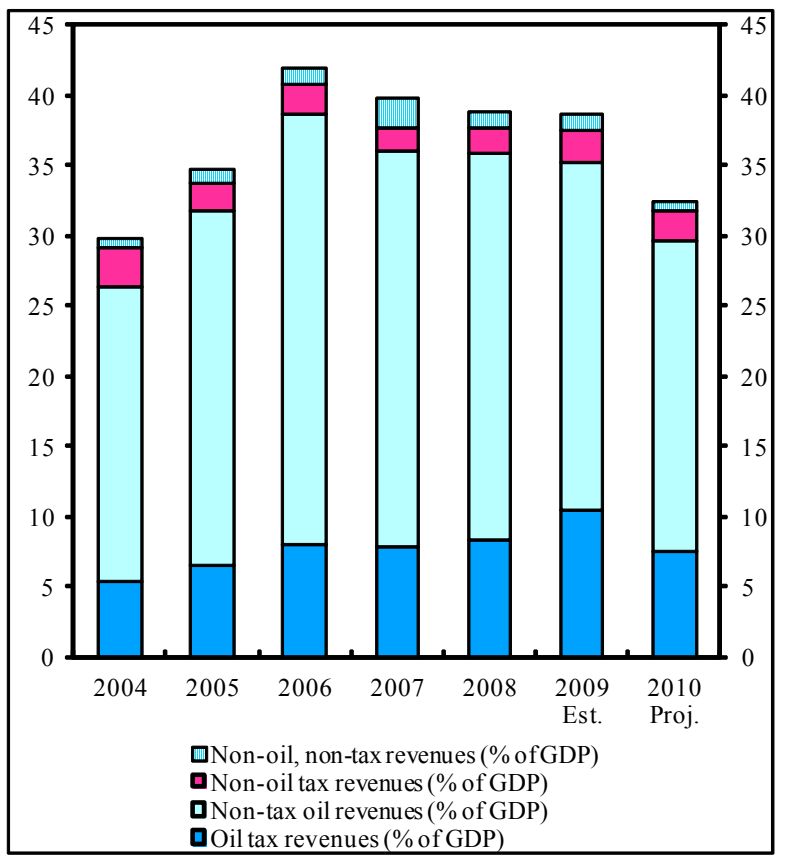

The overall balance swung into deficit while the non-oil primary deficit deteriorated to over 100 percent of non-oil GDP...

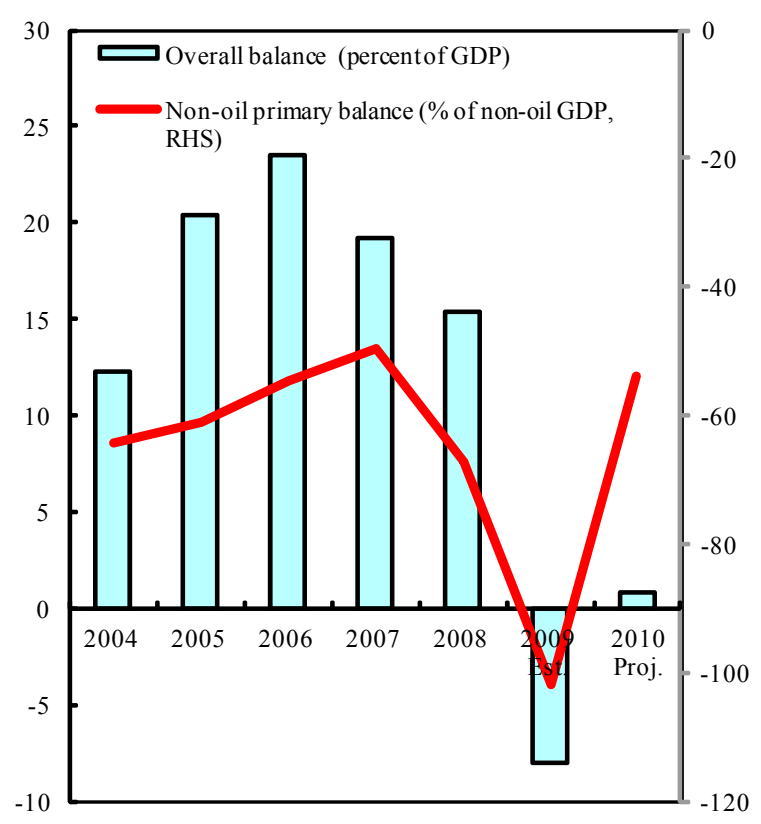

...while capital expenditures soared.

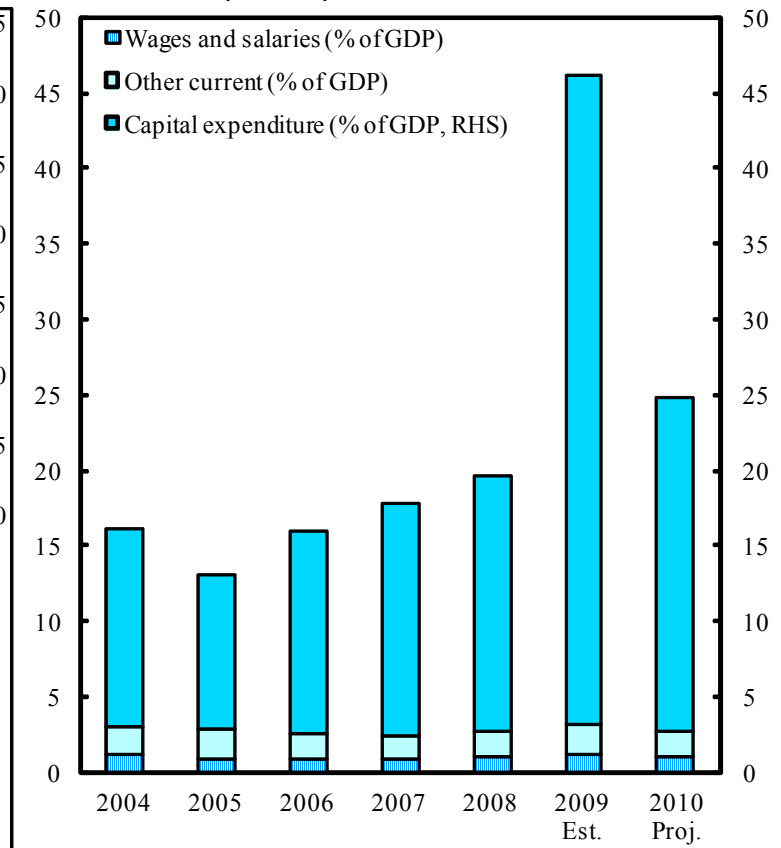

... financed by renewed government borrowing and a drawdown of savings.

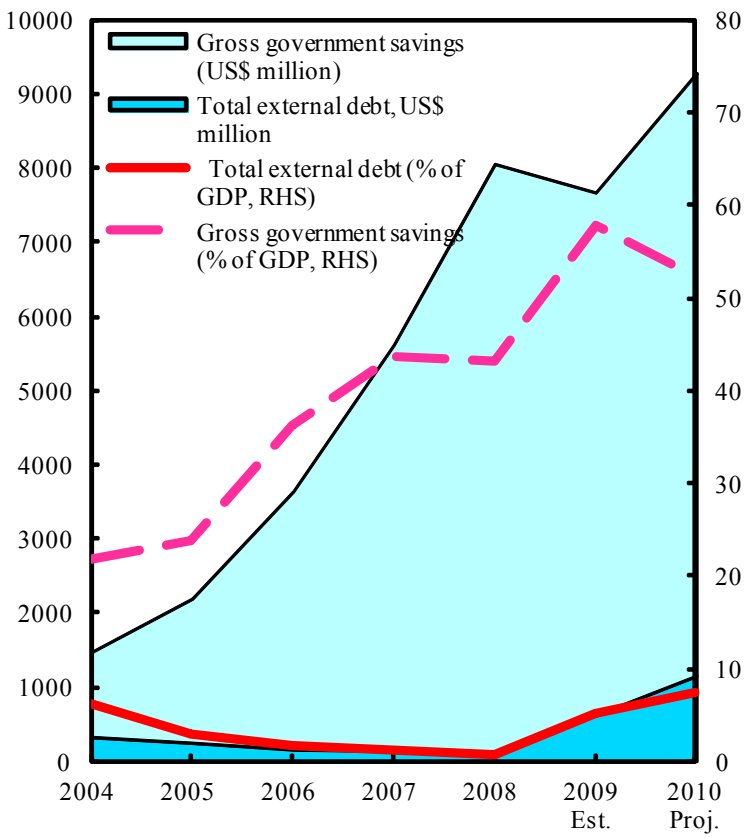

Sources: National authorities, and IMF staff estimates. 


\section{Liquidity remained ample, rising toward end year as government spending} increased. Interest rates edged down, in line with declining international rates and an increase in competition amongst banks for big customers.

\section{The underdeveloped financial system was unscathed by the global financial} turmoil, and appears generally sound. Total outstanding credit at end-2009 was small at $3 \frac{1}{2}$ percent of GDP. There is no evidence of capital repatriation by foreign banks, and exposure to complex derivatives by local subsidiaries was nil. Identified problems in a small, weaker bank have been broadly resolved by a new strategic partner, and banks report having no difficulty in meeting new capital requirements. ${ }^{3}$ While financial sector soundness indicators do not raise red flags, they are volatile due to the fact that credit to the private sector is concentrated in very short-term lending to government contractors. ${ }^{4}$ Increasing use of certification-prior-to-payment on public projects starting in January 2009 led to a temporary rise in nonperforming loans, most of which were resolved within six months as project completion progressed and the government made payments to contractors.

\section{Outlook and Risks}

\section{The medium-term outlook is clouded by the onset of declining hydrocarbon} production and a nascent non-oil sector, with policies posing additional risks. With a negative contribution from oil, overall growth is expected to be significantly lower in the future than during the oil boom, averaging about $1 \frac{1}{2}$ percent (Figure 3 ). The authorities expect robust growth in the small nonhydrocarbon sector, as investments in basic infrastructure begin to bear fruit and new public investments support continued construction activity. Transportation is projected to grow steadily (ports, roads), with construction of a second LNG train and hosting of two official regional events providing an additional boost over the next few years. However, as the PIP winds down and hydrocarbon production tapers off, activity will increasingly need to be driven by private sector activity, which depends on the ability to strengthen productivity and improve the business climate. With prospects for rapid export diversification low, the current account would remain in deficit, mostly reflecting the large import component of the public investment program. The external position would weaken, with government savings dropping sharply as falling oil revenues fail to cover strong planned spending. With the PIP winding down, public external debt would resume a downward trend post-2012 and remain robust to standard shocks.

\footnotetext{
${ }^{3}$ By end-2012, banks must increase registered capital to 10 billion CFAF ( 5 billion minimum end-2009).

${ }^{4}$ At end-2009, over 85 percent of lending was short term, with over three-quarters financing construction related to public investment, backed by what is perceived in most cases to be a government guarantee. Contractors place little of their own capital at risk as government provides an initial project advance. The distribution of bank assets between credit and excess reserves tends to swing sharply from month to month, mirroring advancement in the construction process.
} 


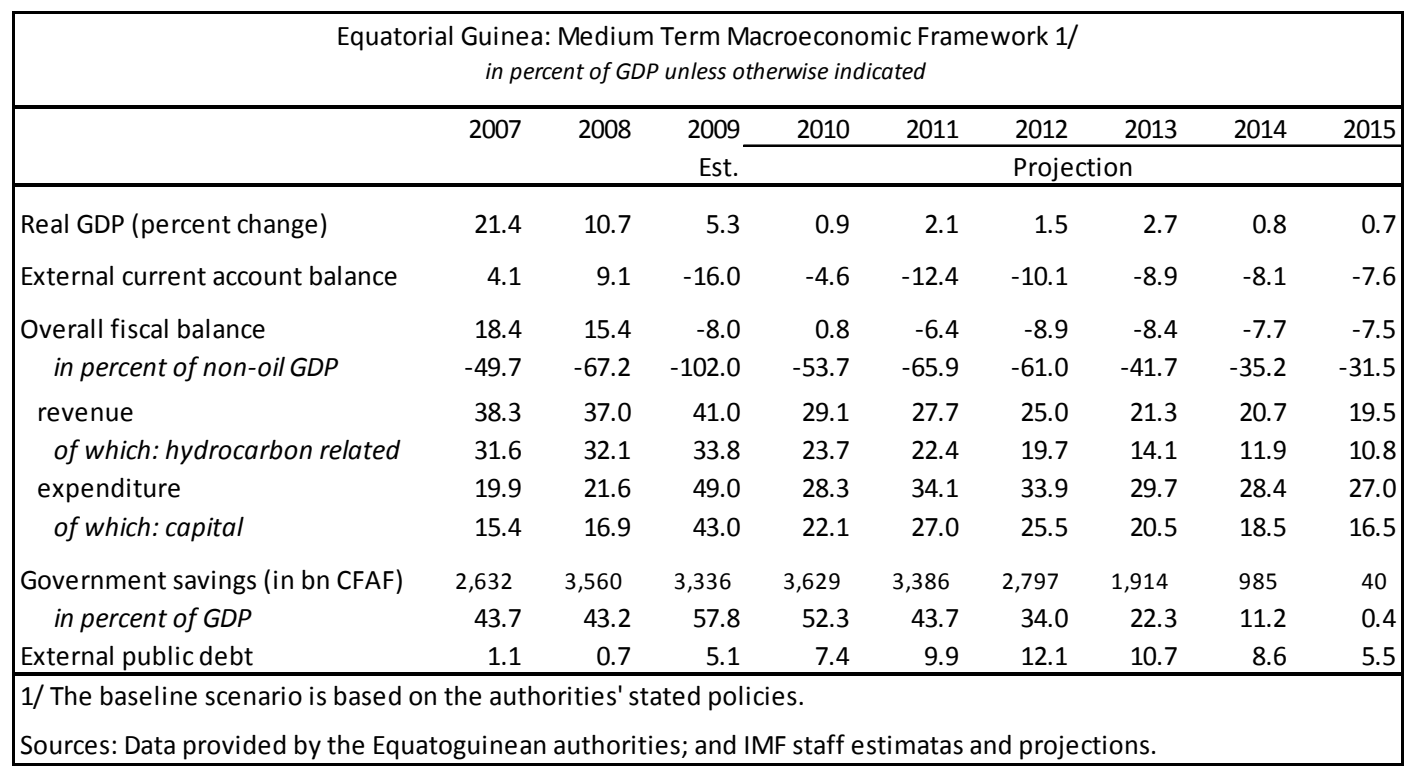

\section{The outlook is subject to significant risks.}

- $\quad$ The economy will continue to be reliant on oil. A negative oil price shock relative to the baseline would further weaken the external position and/or necessitate a sharp fiscal adjustment. Heightened political risk could depress foreign direct investment.

- $\quad$ High public investment may not translate into non-oil growth — with over 1,000 projects in the PIP, implementation and absorptive capacity may become strained, leading to lower investment efficiency than assumed under the baseline.

- $\quad$ Diversification of the economy may stall under slow progress on key structural reforms to improve the business climate, reducing growth prospects.

- On the upside, new oil discoveries would increase oil wealth and growth over the production period, but the fiscal and external sectors would remain highly vulnerable to oil price volatility. ${ }^{5}$

\section{Policy Discussions}

With the economy transitioning to what is projected to be the post-oil period, discussions focused on policy adjustments aimed at achieving fiscal sustainability, raising investment efficiency, improving public financial management, and supporting economic diversification.

\footnotetext{
${ }^{5}$ Oil exploration is ongoing, but no new finds have been announced. Minerals may provide another source of income, however, lack of a mining law may hold back development in this sector.
} 
Figure 3. Equatorial Guinea: Medium-Term Projections, 2007-15

Falling oil production will drag on headline growth while non-oil activity expands moderately...

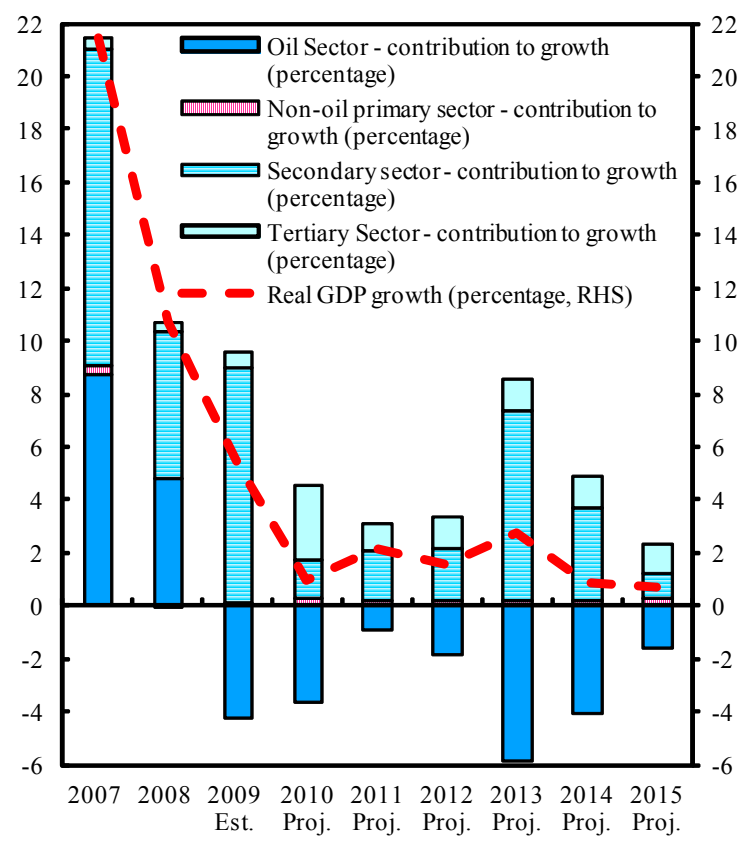

... a weaking of the external position...

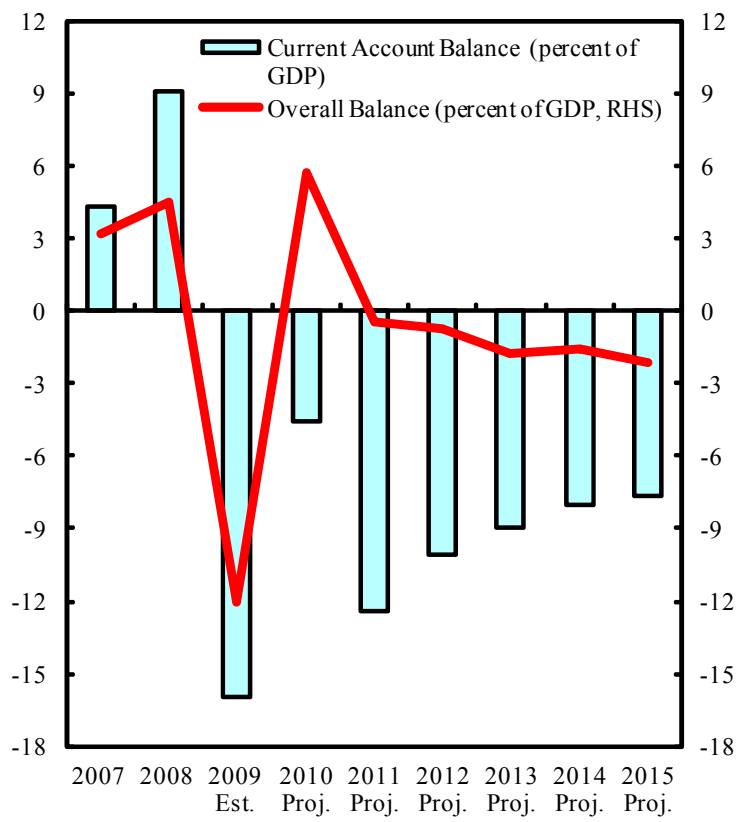

...buoyed by large planned public investment spending which leads to a sustained deficit...

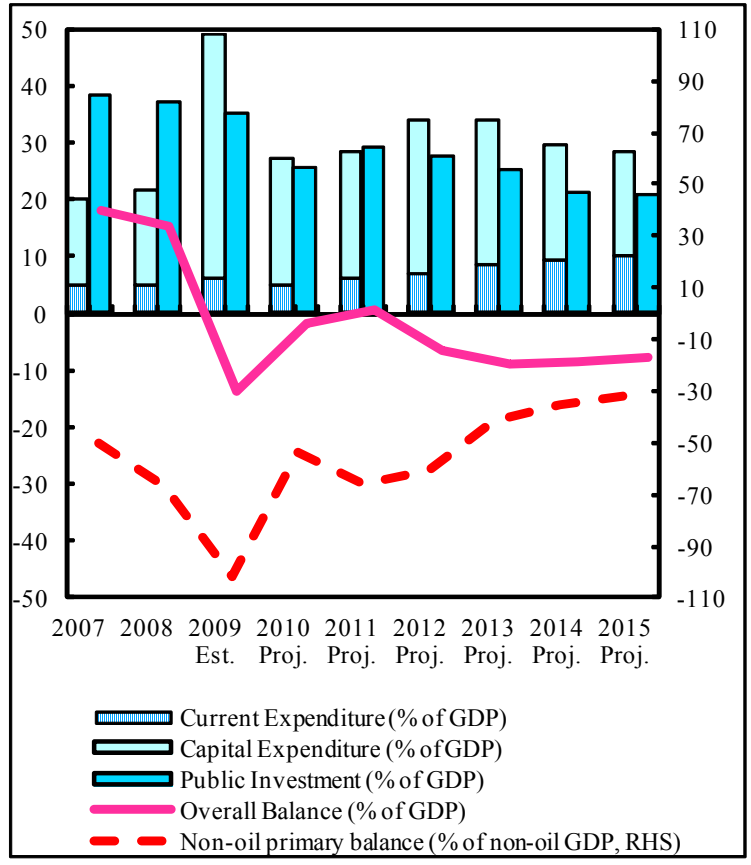

... and a near depletion of government savings.

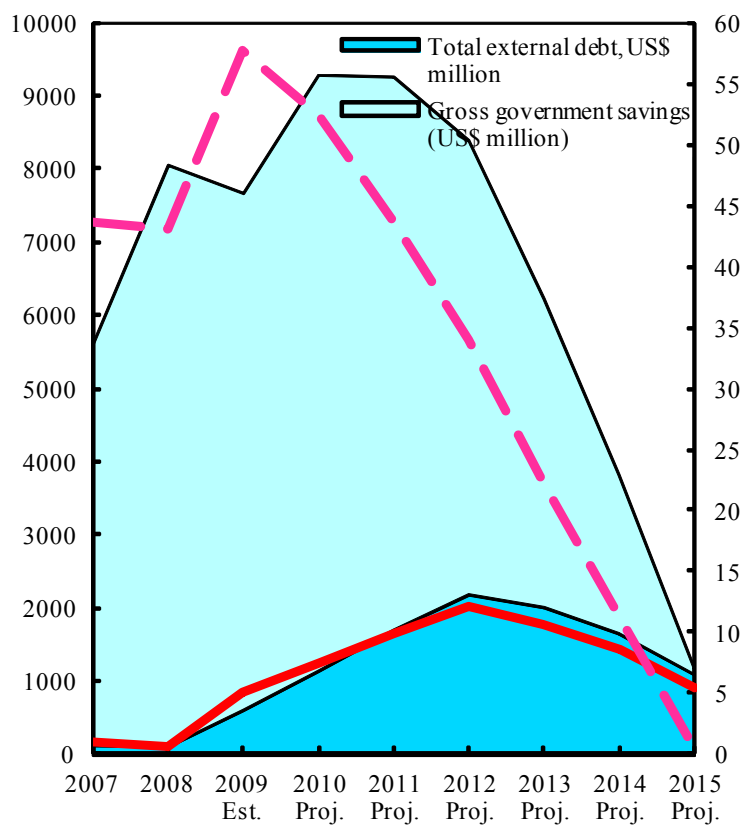

Sources: National authorities, and IMF staff estimates. 


\section{A. Strengthening external stability through sustainable fiscal policy}

9. Given current projections for oil prices and production, the authorities concurred, in principle, on the need for expenditure rationalization. Staff calculations indicate that planned expenditure would exceed expected revenue over the medium term, leading to a near depletion of the stock of government savings by 2015 and a significant weakening of external stability. Moreover, investment of such a magnitude may spur inflationary pressures and drag on competitiveness. With few prospects to increase revenue markedly over the near term, a reduction in investment expenditure would be needed.

10. In recognition of large development needs, the authorities noted that social expenditure should not only be protected but increased, and investment efficiency safeguarded. On expenditure outside of the social area, high-return projects should continue, with staff noting apparent scope to further prioritize, re-phase and/or right-size lower productivity investments to be closer in line with expected medium-term activity. Non-priority investments should be eliminated.

11. The authorities saw little scope to reduce spending over the near-term due to upcoming commitments made when oil prices were high. Construction of facilities to host the African Leader's Summit (2011) and African Cup of Nations (2012) are underway, and basic infrastructure projects in both social and productive areas must be completed in order to support future economic activity.

12. Nonetheless, the authorities are taking actions aimed at increasing savings over the medium term. They noted that while expenditure is expected to decline significantly once basic infrastructure is complete, there is growing awareness of the desirability of adjustment over the near term. A high-level committee has been formed to study project prioritization, and a supervisory body is being established, whose role will be to strengthen expenditure quality and control, including through reducing collusion between project managers and construction companies. Moreover, they envisioned that revenues from any new oil fields would go toward increasing savings.

\section{Staff recommended that starting in 2010, initial steps be taken to place fiscal} policy on a sustainable path through reversing the loosening that occurred in 2009. Targeting a NOPD of around 40 percent of GDP is feasible and desirable, as frontloading the adjustment would reduce vulnerability, strengthen the external position and lessen the need for a sharper adjustment down the road. Near-term adjustment of such a magnitude would also address the risk of large budgetary overruns in 2010-11, which the authorities agree could be potentially large. ${ }^{6}$ In contrast, staff agreed with the authorities that moving

\footnotetext{
${ }^{6}$ In part reflecting weaknesses in the budget process, the 2010 budget envisions a large reduction in infrastructure spending which is inconsistent with the spending profile of existing and planned new projects.
} 
immediately to a position consistent with a constant annuity under a permanent income model (PIM) would imply an undesirably large fiscal adjustment which leaves insufficient space to address pressing development needs. Such an adjustment would imply a reduction in capital expenditure by some 75 percent, and abandonment of many projects already in train.

\section{Staff recommended an alternative expenditure scenario which provides} sufficient fiscal space for priority projects while placing the fiscal position on a path to sustainability. Specifically, staff suggested limiting investment expenditure over 2010-12 to 1,200 billion CFAF - somewhat above the level contained in the authorities' 2009 revised budget - which places the NOPD firmly on a declining path. This amounts to a reduction of about 25 percent in planned expenditure, but fully covers investments in train with room for new priority projects. Post-2012, as projects are completed, expenditure should be reduced further. Somewhat lower construction activity and growth may result from eliminating inefficient projects, but the impact going forward is expected to be limited due to rising investment efficiency. ${ }^{7}$ Under such an expenditure path, the NOPD would be reduced significantly, with government savings rising over the medium term.

\begin{tabular}{|c|c|c|c|c|c|c|c|c|}
\hline \multicolumn{9}{|c|}{ Equatorial Guinea: Fiscal Sustainability Assessment } \\
\hline & & $\begin{array}{l}\text { Dverall } \\
\text { percent }\end{array}$ & & & & $\begin{array}{l}\text { oil prim } \\
\text { ent of }\end{array}$ & $\begin{array}{l}\text { balance } \\
\text { iil GDP }\end{array}$ & \\
\hline Baseline proiection (authorities' nolicies) & 2010 & 2011 & 2012 & 2015 & 2010 & 2011 & 2012 & 2015 \\
\hline Fiscal balance & 0.8 & -6.4 & -8.9 & -7.5 & -53.7 & -65.9 & -61.0 & -31.5 \\
\hline Stock of gross government savings & 52.3 & 43.7 & 34.0 & 0.4 & 122.9 & 100.5 & 73.3 & 0.71 \\
\hline \multicolumn{9}{|l|}{ Staffs alternative expenditure scenario } \\
\hline Fiscal balance & 5.6 & 5.4 & 2.5 & 0.6 & -42.7 & -39.9 & -38.1 & -20.7 \\
\hline Stock of gross government savings & 57.2 & 61.4 & 65.7 & 68.9 & 134.7 & 142.8 & 144.3 & 114.3 \\
\hline Required adjustment versus baseline & 4.8 & 11.8 & 11.4 & 8.1 & 11.0 & 26.0 & 22.9 & 10.8 \\
\hline \multicolumn{9}{|l|}{ Permanent Income Model (constant annuity) } \\
\hline Overall fiscal balance & 17.2 & 16.8 & 14.1 & 5.8 & -15.2 & -14.2 & -13.3 & -10.8 \\
\hline Stock of gross government savings & 65.3 & 75.3 & 85.0 & 98.9 & 153.4 & 173.1 & 183.2 & 161.1 \\
\hline Required adjustment versus baseline & 16.4 & 23.2 & 22.9 & 13.3 & 38.5 & 51.7 & 47.7 & 20.7 \\
\hline
\end{tabular}

\section{The fiscal adjustment under the staff's expenditure scenario also addresses} concerns regarding external stability. The exchange rate peg has served the economy well, but falling oil production and unsustainable planned expenditure would weaken the external position over time. All specifications and approaches employed to assess external stability point to the need for a substantially higher current account balance than under the

Staff estimate potential overruns relative to budget of some 7 percentage points of GDP in 2010. Nonetheless, the baseline scenario does fully capture the authorities' triennial spending plan for 2010-12.

${ }^{7}$ Given the high import component of spending, under staff's scenario, growth would average 1 percent per year over the medium term versus $1 \frac{1}{2}$ percent under the baseline due to lower construction activity. 
policy-dependent baseline. The macroeconomic balance and external sustainability approaches (under various allocation rules) both yield a (minimum) required current account adjustment of some 15 percentage points of GDP in 2015 - a magnitude which could not be achieved without fiscal adjustment. With non-oil private sector imports stable at about 7 percent of GDP over the medium term and oil accounting for 99 percent of exports, policies should aim to lower public expenditure-related imports ( 75 percent of total imports) and support successful economic diversification. This result is consistent with the findings for the CEMAC region as a whole, which indicate that external stability requires regionally higher public savings and structural reforms to bring the real effective exchange rate in line with medium-term fundamentals (IMF Country Report No. 09/267).

16. Discussions also centered on ways to strengthen non-oil revenue. The authorities shared staff's concern about sharply falling oil revenues in the context of increasing current expenditure pressures - notably, on operations and maintenance of sizeable public investments. They saw scope for further improvements in tax administration, including through modernization of the tax and customs departments. They are also creating autonomous public agencies charged with upkeep of public investment, such as roads and buildings. As diversification progresses, road maintenance would become increasingly self-financing through tolls, while additional revenue from growing port services and possible export of electricity is also envisioned. Staff highlighted that going forward tax holidays should be limited, while increased government savings over the medium term would provide an additional source of financial income down the road.

\section{B. Public Financial Management: Strong institutions and governance}

\section{The large over-execution of investment expenditure in 2009 points to weak} budgetary control, while apparent under-budgeting of 2010 spending is indicative of deficiencies in the budget process. ${ }^{8}$ The authorities noted that current spending is well controlled and progress in tracking PIP expenditure has been made with the assistance of two macrofiscal advisors backstopped by the IMF, but agreed that insufficient coordination among departments and between ministries surrounds the PIP.

18. The authorities noted that capacity constraints and other hurdles would need to be overcome to improve PFM. Unreliable electricity supply and communication networks would have to be resolved to ensure uninterrupted processing and recordation of fiscal transactions. However, basic infrastructure should be in place by 2012; collaboration on developing appropriate software to record transactions is ongoing; and technical assistance is serving to improve capacity. Moreover, investment efficiency should be enhanced by the new supervisory body charged with overseeing disbursement of payments to contractors and

\footnotetext{
${ }^{8}$ In 2009, the World Bank conducted a public expenditure review (PER), which has been sent to the authorities for comment. The draft PER points to weaknesses in most areas of public financial management.
} 
planned use of outside experts for pre-project analysis in areas which the relevant line ministry does not have expertise.

19. The authorities have demonstrated their commitment to improved transparency through progress on the Extractive Industries Transparency Initiative (EITI). After initial delays, the EITI process is progressing rapidly, as previously confidential information on state oil companies has been released. The final reconciliation report has been posted on the internet and validation is underway. An extension past the March 9, 2010 deadline was requested to complete validation and tie up loose ends.

20. On reserve holdings, the authorities reiterated their commitment to CEMAC but noted that in light of the losses incurred in the recent fraud scandal they would not increase holdings in BEAC until the situation had been fully resolved. At an operational level, financing the fiscal deficit through running down BEAC deposits while increasing offshore holdings is financially advantageous, given BEAC's lower remuneration. Nonetheless, the authorities reaffirmed their readiness to switch deposits into BEAC to strengthen support for the exchange rate peg, if necessary.

\section{Economic diversification and private sector-led growth}

With hydrocarbon production expected to taper off, Equatorial Guinea will need to advance other sources of value added if development is to be sustained. Successful diversification requires strong human capital, financial intermediation, and an enabling business environment.

\section{Guided by the framework in their NDP, the authorities aim to graduate to} emerging country status by 2020. In view of the exhaustible nature of oil resources, sustained growth would be achieved through economic diversification (Box 1). In the current phase (2008-12), oil wealth is being used to build up basic infrastructure. Longer-term policies will aim to strengthen the business climate and foster identified sectors of potential growth and employment creation. Current business climate indicators point to a wide-ranging structural reform agenda. ${ }^{9}$

\footnotetext{
${ }^{9}$ Despite much higher income, Equatorial Guinea ranks 170 of 183 countries on the World Bank's Doing Business 2010, in line with sub-Saharan Africa peers. It ranks somewhat below regional peers on Transparency International's Corruption Perceptions Index (2009).
} 


\section{Box 1. National Development Plan 2020: Potential Sources of Growth and Diversification}

The authorities' NDP identifies key areas of potential growth and employment creation based on resource allocation and geographic location. Diversification is expected to be further supported by increasing regional integration and investment in basic infrastructure. Identified sectors of potential growth include:

- $\quad$ Fishing and aquaculture, as well as agriculture aimed at food security and import substitution, with limited scope for export of traditional agricultural commodities;

- $\quad$ Transport services, via both ports and roads;

- $\quad$ Tourism, including officially sanctioned events and eco-tourism; and

- $\quad$ Financial services.

22. In recognition of the important role to be played by small- and mediumenterprises (SMEs), the authorities are beginning to work with the banking sector on improving access to financing. Modalities are yet to be decided but proposals include creation of a credit fund (i.e., a long-term government deposit) which banks could loan out at concessional rates, a guarantee fund, or a direct interest rate subsidy.

23. More broadly, the authorities support regional initiatives to strengthen financial sector development. Improvements over the past year include real-time interbank clearance and ATM machines at the individual bank level. The fiber-optic cable to the mainland should be operational by end-year, allowing faster and more reliable real-time information transfer from the island. Work is also ongoing on introducing an ATM network, use of credit cards, and a government debt market to facilitate liquidity management.

\section{Outside of the financial sector, the authorities' diversification strategy envisions} the government facilitating, not competing with, the private sector. The national strategy should be seen in the context of the larger regional strategy to strengthen CEMAC integration and graduate to emerging market status by 2025 - ports and highways in Equatorial Guinea are a key pillar to increased trade. Over the near-term, the authorities will also continue to orient the economy toward identified key sectors (agriculture, fishing, tourism), filling the void left by an unwilling private sector through creation of public companies and agencies, as they have done in the management of public investment (highways, real estate).

25. There was broad agreement that not all conditions were yet in place which would allow for rapid emergence of a predominantly non-oil economy. Increased 
spending on human capital development at all levels is underway, although much more is required, especially on increasing the number of teachers and healthcare professionals. Given the large reform agenda and capacity constraints, the authorities noted that once basic infrastructure is sufficiently advanced work in other areas would be stepped up, including in some cases on needed legal reforms.

\section{DATA ISSUES}

26. The authorities are fully aware of severe data deficiencies, and are seeking to ramp up technical assistance (Informational Annex). The World Bank recently identified a resident national accounts consultant who should begin work soon, and a grant request is being prepared to fund technical assistance to prepare and supervise the implementation of a household survey. Long-awaited improvements in population data should result from the census slated for 2011.

\section{Staff Appraisal}

27. Equatorial Guinea faces immense challenges. The outlook is clouded by declining oil production, but policies pose significant risks to macroeconomic and external stability. Policy adjustment is needed but must balance risks against development needs. A large fiscal adjustment is required but feasible, and should be frontloaded. Over the medium term, oil dependence will continue, with longer-term prospects dependant on the ability to develop alternative sources of value added through economic diversification.

28. Moving toward a sustainable fiscal position starting in 2010 would halt the projected near-depletion of the stock of government savings and strengthen external stability. The NOPD should be brought down to around 40 percent of non-oil GDP in 2010 and be placed on a downward path thereafter - a spending envelope which fully covers projects in train with space for additional priority projects aimed at improving living standards and productivity today and in the future. With few near-term prospects for a sizeable increase in non-oil revenue, adjustment would have to come through lower expenditure. Significant scope may also exist to rationalize and right-size productive investment in line with expected future economic needs. Non-priority projects should be scrapped and new sources of non-oil revenue should be sought.

29. Strengthening public financial management is critical. Improved budget planning and control, particularly over public investment, are urgently required to ensure the effective spending of oil wealth and improve macroeconomic management. Investment efficiency would also be strengthened by redoubled efforts at prioritization, increased use of project appraisals and better coordination across agencies.

30. EITI should be viewed as part of an on-going commitment to improved transparency and governance. With initial reconciliation complete, efforts should be broadened, including through publication of contract awards and audit reports. More 
generally, increased dissemination of information on government operations, including foreign asset holdings, would demonstrate commitment in this area.

31. The exchange rate regime has served the country well, however, unsustainable planned fiscal spending poses risks to external stability. The projected near-depletion of the stock of government savings has stark implications for the stability of the region, given the nation's considerable weight in regional foreign asset holdings. More broadly, for the CEMAC region as a whole, external stability requires regionally higher public savings and productivity-enhancing structural reforms to bring the real effective exchange rate in line with medium-term fundamentals.

\section{In this context, the authorities should comply with their obligations under}

CEMAC. The recent shift in reserve management not only implies a smaller contribution to the CEMAC common pool of reserves, it marks an increase in exposure to oil price volatility, rising future debt service, and lower holding of risk-free assets. Government savings should be strengthened and the decline in the share of foreign assets held in BEAC reversed. Overexposure to oil and risky assets should be avoided, as should contractual debt obligations which are not warranted on financial grounds.

\section{The wide-ranging goals of the NDP necessitate a comprehensive approach to} development and poverty alleviation. Notwithstanding capacity constraints, the time has come to move beyond infrastructure and focus increasing attention on actions to strengthen human capital and improve the business climate. Collaboration with the banking sector on facilitating lending to SMEs should continue, but it will be key to limit potential contingent liabilities. Support for regional initiatives aimed at financial market development should also continue, especially those aimed at lengthening loan maturity and reducing reliance on implicit government guarantees. The integrity of the system would be enhanced by operationalizing the national financial investigation agency (ANIF) charged with anti-money laundering and combating the financing of terrorism (AML-CFT). Outside of the financial sector, removal of barriers to private sector activity and reducing regulatory discretion are crucial, and will allow lagged growth effects from infrastructure investment to play out more fully. More competitive goods markets would also serve to bring down prices, increasing the purchasing power of Equatoguineans, while improvements in productivity will help raise competitiveness.

\section{Data deficiencies are severe and hamper assessment of economic developments} and policy formulation. The 2011 Census should resolve longstanding discrepancies on population figures and should be complemented by a household expenditure survey which could inform future social policies. Capacity building through technical assistance should continue, with the aim of participating in GDDS as improvements are made.

35. It is recommended that the next Article IV consultation with Equatorial Guinea take place on the standard 12-month cycle. 
Table 1. Equatorial Guinea: Selected Economic and Financial Indicators, 2006-10

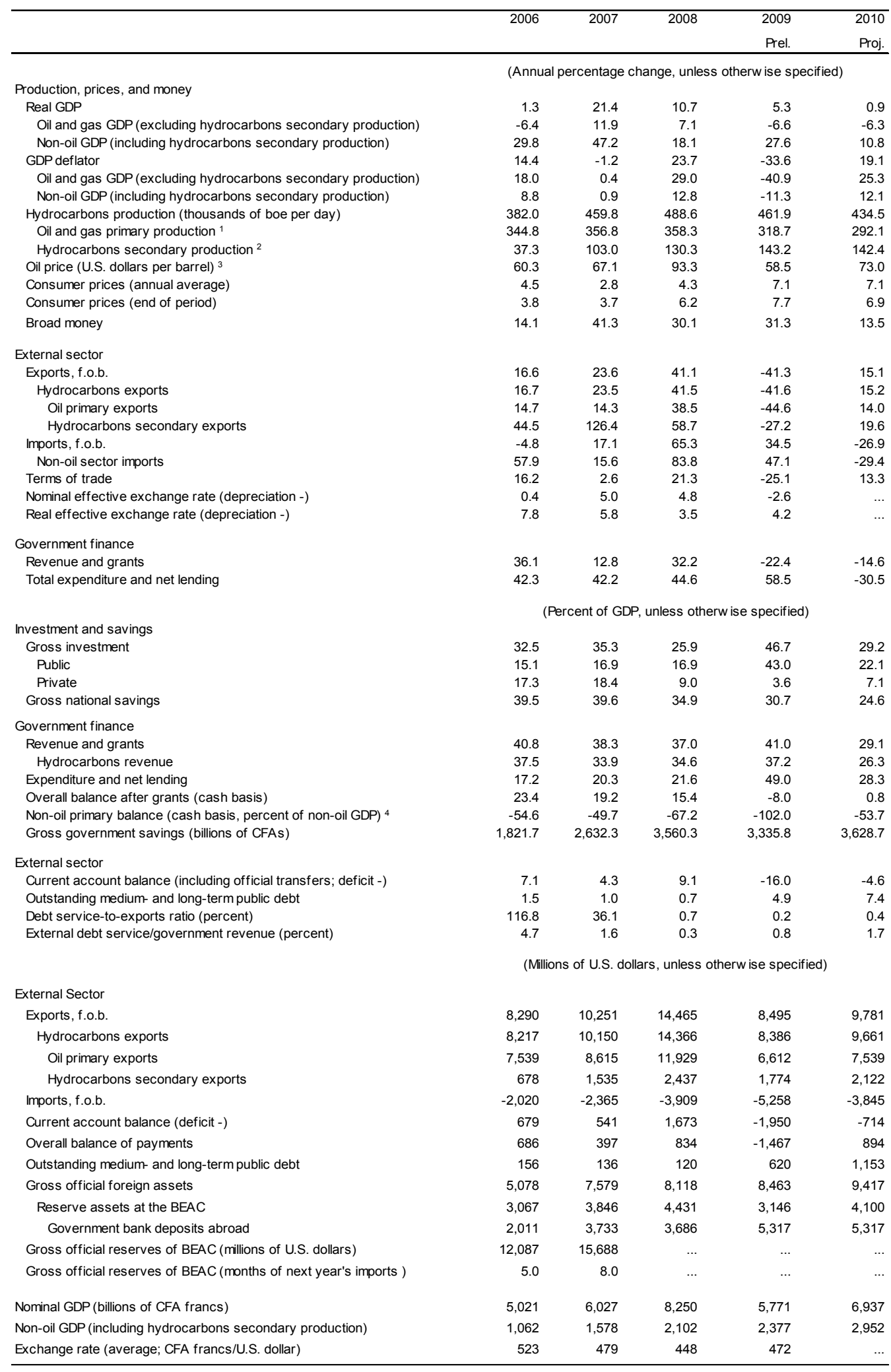

Sources: Data provided by the Equatoguinean authorities; and staff estimates and projections.

1 Including oil and natural gas.

2 Including LNG, LPG, butane, propane, and methanol.

${ }^{3}$ The price of oil is the average of three spot prices: dated Brent, West Texas Intermediate, and Dubai Fateh; and includes a discount for quality.

${ }^{4}$ Excluding oil revenues, oil-related expenditures, and interest earned and paid. 
Table 2. Equatorial Guinea: Summary of Real Sector Developments, 2006-10

\begin{tabular}{|c|c|c|c|c|c|}
\hline & 2006 & 2007 & 2008 & $\begin{array}{c}2009 \\
\text { Est. }\end{array}$ & $\begin{array}{r}2010 \\
\text { Proj. }\end{array}$ \\
\hline & \multicolumn{5}{|c|}{ GDP by sector of origin } \\
\hline & \multicolumn{5}{|c|}{ (Billions of CFA francs at 2000 prices) } \\
\hline GDP & $3,018.3$ & $3,665.2$ & $4,056.9$ & $4,273.0$ & $4,313.3$ \\
\hline Non-oil GDP & 814.4 & $1,198.7$ & $1,415.7$ & $1,805.8$ & $2,001.3$ \\
\hline Primary sector & $2,312.7$ & $2,586.1$ & $2,759.3$ & $2,588.7$ & $2,445.8$ \\
\hline Non-oil & 108.8 & 119.6 & 118.1 & 121.6 & 133.8 \\
\hline Oil & $2,203.9$ & $2,466.4$ & $2,641.2$ & $2,467.1$ & $2,312.0$ \\
\hline Secondary sector & 584.1 & 945.3 & $1,150.3$ & $1,511.0$ & $1,571.9$ \\
\hline Oil derivatives & 254.1 & 516.9 & 615.1 & 669.3 & 660.6 \\
\hline Non-derivatives & 330.0 & 428.5 & 535.2 & 841.8 & 911.4 \\
\hline Tertiary sector & 101.4 & 112.9 & 124.0 & 148.7 & 270.6 \\
\hline \multirow[t]{2}{*}{ Import duties and subsidies } & 20.0 & 20.9 & 23.3 & 24.5 & 25.0 \\
\hline & \multicolumn{5}{|c|}{ (Annual percentage change in constant prices) } \\
\hline GDP & 1.3 & 21.4 & 10.7 & 5.3 & 0.9 \\
\hline Non-oil GDP & 29.8 & 47.2 & 18.1 & 27.6 & 10.8 \\
\hline Primary sector & -5.9 & 11.8 & 6.7 & -6.2 & -5.5 \\
\hline Non-oil & 3.7 & 10.0 & -1.3 & 3.0 & 10.0 \\
\hline Oil & -6.4 & 11.9 & 7.1 & -6.6 & -6.3 \\
\hline Secondary sector & 42.1 & 61.8 & 21.7 & 31.4 & 4.0 \\
\hline Oil derivatives & 14.9 & 103.4 & 19.0 & 8.8 & -1.3 \\
\hline Non-derivatives & 73.8 & 29.8 & 24.9 & 57.3 & 8.3 \\
\hline Tertiary sector & 8.1 & 11.3 & 9.9 & 19.8 & 82.0 \\
\hline \multirow[t]{2}{*}{ Import duties and subsidies } & 14.0 & 4.2 & 11.4 & 5.5 & 2.0 \\
\hline & \multicolumn{5}{|c|}{ (Percent of GDP) } \\
\hline GDP & 100.0 & 100.0 & 100.0 & 100.0 & 100.0 \\
\hline Non-oil GDP & 27.0 & 32.7 & 34.9 & 42.3 & 46.4 \\
\hline Primary sector & 76.6 & 70.6 & 68.0 & 60.6 & 56.7 \\
\hline Non-oil & 3.6 & 3.3 & 2.9 & 2.8 & 3.1 \\
\hline Oil & 73.0 & 67.3 & 65.1 & 57.7 & 53.6 \\
\hline Secondary sector & 19.4 & 25.8 & 28.4 & 35.4 & 36.4 \\
\hline Oil derivatives & 8.4 & 14.1 & 15.2 & 15.7 & 15.3 \\
\hline Non-derivatives & 10.9 & 11.7 & 13.2 & 19.7 & 21.1 \\
\hline Tertiary sector & 3.4 & 3.1 & 3.1 & 3.5 & 6.3 \\
\hline \multirow[t]{3}{*}{ Import duties and subsidies } & 0.7 & 0.6 & 0.6 & 0.6 & 0.6 \\
\hline & \multicolumn{5}{|c|}{ GDP by use of resources } \\
\hline & \multicolumn{5}{|c|}{ (Billions of CFA francs at current prices) } \\
\hline GDP & $5,021.4$ & $6,026.8$ & $8,250.2$ & $5,771.2$ & $6,937.1$ \\
\hline Net factor income from abroad & $-2,321.6$ & $-2,828.7$ & $-3,113.4$ & $-1,573.0$ & $-2,193.4$ \\
\hline Gross national product & $2,699.8$ & $3,198.1$ & $5,136.8$ & $4,198.1$ & $4,743.6$ \\
\hline Unrequited transfers & -17.6 & -21.9 & -36.1 & -49.9 & -56.4 \\
\hline Gross disposable income & $2,682.2$ & $3,176.2$ & $5,100.7$ & $4,148.3$ & $4,687.2$ \\
\hline Consumption & 696.3 & 790.7 & $2,218.1$ & $2,376.9$ & $2,978.8$ \\
\hline National savings & $1,986.0$ & $2,385.5$ & $2,882.6$ & $1,771.3$ & $1,708.4$ \\
\hline Gross capital formation & $1,630.7$ & $2,126.0$ & $2,133.5$ & $2,692.3$ & $2,026.3$ \\
\hline External current account & 355.2 & 259.5 & 749.1 & -920.9 & -317.9 \\
\hline & \multicolumn{5}{|c|}{ (Percent of GDP) } \\
\hline GDP at market prices & 100.0 & 100.0 & 100.0 & 100.0 & 100.0 \\
\hline Net factor income from abroad & -46.2 & -46.9 & -37.7 & -27.3 & -31.6 \\
\hline Gross national product & 53.8 & 53.1 & 62.3 & 72.7 & 68.4 \\
\hline Unrequited transfers & -0.4 & -0.4 & -0.4 & -0.9 & -0.8 \\
\hline Gross disposable income & 53.4 & 52.7 & 61.8 & 71.9 & 67.6 \\
\hline Consumption & 13.9 & 13.1 & 26.9 & 41.2 & 42.9 \\
\hline National savings & 39.5 & 39.6 & 34.9 & 30.7 & 24.6 \\
\hline Gross capital formation & 32.5 & 35.3 & 25.9 & 46.7 & 29.2 \\
\hline External current account & 7.1 & 4.3 & 9.1 & -16.0 & -4.6 \\
\hline Trade balance & 53.7 & 51.6 & 47.3 & 12.2 & 27.8 \\
\hline
\end{tabular}

Sources: Equatoguinean authorities; and staff estimates and projections. 
Table 3. Equatorial Guinea: Balance of Payments, 2006-10 1 (Millions of U.S. dollars, unless otherw ise specified)

\begin{tabular}{|c|c|c|c|c|c|}
\hline & 2006 & 2007 & 2008 & $\begin{array}{r}2009 \\
\text { Est. }\end{array}$ & $\begin{array}{r}2010 \\
\text { Proj. }\end{array}$ \\
\hline Current account & 679 & 541 & 1,673 & $-1,950$ & -714 \\
\hline Trade balance & 6,270 & 7,886 & 10,555 & 3,237 & 5,936 \\
\hline Exports of goods, f.o.b. & 8,290 & 10,251 & 14,465 & 8,495 & 9,781 \\
\hline Hydrocarbons exports & 8,217 & 10,150 & 14,366 & 8,386 & 9,661 \\
\hline Imports of goods, f.o.b. & $-2,020$ & $-2,365$ & $-3,909$ & $-5,258$ & $-3,845$ \\
\hline Petroleum sector & -525 & -636 & -733 & -587 & -548 \\
\hline Petroleum products & -114 & -149 & -253 & -177 & -212 \\
\hline Public sector equipment & $-1,189$ & $-1,319$ & $-2,486$ & $-3,943$ & $-2,408$ \\
\hline Other $^{2}$ & -192 & -260 & -437 & -551 & -677 \\
\hline Services (net) & $-1,117$ & $-1,397$ & $-1,849$ & $-1,750$ & $-1,598$ \\
\hline Income (net) ${ }^{3}$ & $-4,440$ & $-5,902$ & $-6,953$ & $-3,331$ & $-4,925$ \\
\hline Current transfers & -34 & -46 & -81 & -106 & -127 \\
\hline Capital and financial account & 109 & -101 & $-1,263$ & 454 & 1,608 \\
\hline Capital account & 0 & 0 & 0 & 0 & 0 \\
\hline Financial account & 109 & -101 & $-1,263$ & 454 & 1,608 \\
\hline Direct investment & 1,739 & 1,716 & -570 & 1,304 & 1,369 \\
\hline Portfolio investment (net) & 0 & 0 & 0 & 0 & 0 \\
\hline Other investment (net) & $-1,630$ & $-1,817$ & -693 & -850 & 239 \\
\hline Medium and long-term transactions & -84 & -22 & -10 & 502 & 532 \\
\hline General government & -95 & -36 & -9 & 503 & 533 \\
\hline Of which: Amortization & -95 & -36 & -9 & -5 & -6 \\
\hline Banks & 0 & 0 & 0 & 0 & 0 \\
\hline Other sectors & 11 & 13 & -1 & -2 & -2 \\
\hline Short-term transactions & $-1,546$ & $-1,794$ & -682 & $-1,351$ & -293 \\
\hline General government 4,5 & $-1,203$ & $-1,831$ & 812 & $-1,437$ & 0 \\
\hline Banks & 49 & -84 & -144 & 92 & -221 \\
\hline Other sectors & -392 & 120 & $-1,351$ & -6 & -71 \\
\hline Errors and omissions & -103 & -44 & 424 & 29 & 0 \\
\hline Overall balance & 686 & 397 & 834 & $-1,467$ & 894 \\
\hline Financing & -686 & -397 & -834 & 1,467 & -894 \\
\hline Change in net international reserves ${ }^{6}$ (increase -) & -686 & -397 & -834 & 1,467 & -894 \\
\hline \multicolumn{6}{|l|}{ Memorandum items: } \\
\hline Gross official foreign assets & 4,247 & 6,651 & 8,012 & 8,463 & 9,417 \\
\hline Reserve assets at the BEAC & 3,067 & 3,846 & 4,431 & 3,146 & 4,100 \\
\hline Of which: Government deposits at BEAC & 2,478 & 3,103 & 3,973 & 2,134 & 2,832 \\
\hline Government bank deposits outside of BEAC & 1,180 & 2,805 & 3,581 & 5,192 & 5,294 \\
\hline Gross government savings & 3,658 & 5,907 & 7,554 & 7,326 & 8,126 \\
\hline Gross official reserves of BEAC (millions of U.S. dollars) & 9,032 & 12,087 & 15,688 & $\ldots$ & $\ldots$ \\
\hline Gross official reserves of BEAC (months of next year's imports ) & 4.7 & 5.0 & 8.0 & $\ldots$ & $\ldots$ \\
\hline Current account balance (percent of GDP; deficit -) & 7.1 & 4.3 & 9.1 & -16.0 & -4.6 \\
\hline Overall balance (percent of GDP; deficit -) & 7.1 & 3.2 & 4.5 & -12.0 & 5.7 \\
\hline Grow th of oil exports, including petroleum derivatives (percent) & 16.7 & 23.5 & 41.5 & -41.6 & 15.2 \\
\hline Grow th of non-oil exports, excluding petroleum derivatives (percent) & 0.1 & 37.1 & -1.6 & 9.4 & 10.7 \\
\hline Grow th of other imports ${ }^{2}$ (percent) & 23.7 & 35.3 & 68.3 & 26.0 & 22.7 \\
\hline
\end{tabular}

Sources: Equatoguinean authorities; and staff estimates and projections.

1 The BOP data in this table are not compiled in accordance w ith the IMF's Balance of Payments Manual, fifth edition. The historic data have not been derived from customs' and bank records' data, but from estimates of BEAC. Fund staff have made ad hoc adjustments to the data.

2 Including private sector consumption and investment imports.

${ }^{3}$ Including investment income of oil companies, wh hich includes reinvested earnings ( $w$ ith an offsetting entry in foreign direct investment).

${ }^{4}$ Includes purchase of Devon's share of oil fields in 2008 by Equatorial Guinea.

${ }^{5}$ Since 2000 , entries represent changes in government deposits in commercial banks abroad.

${ }^{6}$ Consists only of items on the balance sheet of the BEAC (i.e., excluding government bank deposits abroad). 
Table 4a. Equatorial Guinea: Summary of Central Government Financial Operations, 2006-10 (Billions of CFA francs, unless otherw ise specified)

\begin{tabular}{|c|c|c|c|c|c|c|}
\hline & 2006 & 2007 & 2008 & 2009 & $\begin{array}{r}2010 \\
\text { Budget }\end{array}$ & $\begin{array}{r}2010 \\
\text { Proj. }\end{array}$ \\
\hline Total revenue and grants & $2,047.1$ & $2,308.5$ & $3,051.8$ & $2,368.1$ & $1,763.2$ & $2,021.6$ \\
\hline Revenue & $2,047.1$ & $2,308.5$ & $3,051.8$ & $2,368.1$ & $1,763.2$ & $2,021.6$ \\
\hline Tax revenue & 510.0 & 472.8 & 688.6 & 905.7 & 555.1 & 523.6 \\
\hline Taxes on income, profits, and capital gains & 466.9 & 424.6 & 647.2 & 847.4 & 494.2 & 456.2 \\
\hline Personal income tax & 34.4 & 62.3 & 38.8 & 59.0 & 53.6 & 50.2 \\
\hline Corporate income tax & 432.3 & 361.8 & 607.8 & 787.2 & 440.2 & 406.0 \\
\hline Other income taxes & 0.2 & 0.5 & 0.5 & 1.2 & 0.4 & 0.0 \\
\hline Domestic taxes on goods and services ${ }^{1}$ & 28.8 & 30.3 & 30.3 & 44.0 & 49.8 & 43.8 \\
\hline Taxes on international trade and transactions & 10.2 & 12.8 & 7.3 & 10.1 & 7.7 & 19.4 \\
\hline Other taxes & 4.0 & 5.2 & 3.9 & 4.2 & 3.4 & 4.3 \\
\hline Nontax revenue & $1,537.1$ & $1,835.7$ & $2,363.2$ & $1,462.4$ & $1,208.1$ & $1,498.0$ \\
\hline Hydrocarbons sector & $1,476.0$ & $1,702.0$ & $2,267.7$ & $1,392.0$ & $1,159.6$ & $1,441.3$ \\
\hline Royalties & 969.9 & $1,130.6$ & $1,618.1$ & $1,095.2$ & 370.2 & 402.0 \\
\hline Profit sharing & 500.3 & 469.5 & 648.6 & 296.4 & 785.4 & $1,029.7$ \\
\hline Bonuses and rents & 5.8 & 101.9 & 1.0 & 0.4 & 4.0 & 9.5 \\
\hline Non hydrocarbons sector & 61.1 & 133.7 & 95.5 & 70.5 & 48.5 & 56.7 \\
\hline Nontax revenue excluding interest on saving funds & 43.9 & 94.4 & 63.0 & 54.1 & 42.5 & 42.5 \\
\hline Interest on saving funds & 17.2 & 39.4 & 32.5 & 16.3 & 6.0 & 14.3 \\
\hline Grants & 0.0 & 0.0 & 0.0 & 0.0 & 0.0 & 0.0 \\
\hline Total expenditure and net lending & 869.7 & $1,152.2$ & $1,783.5$ & $2,827.5$ & $1,875.1$ & $1,966.2$ \\
\hline Current expenditure & 199.4 & 214.5 & 392.0 & 345.3 & 343.2 & 434.3 \\
\hline Wages and salaries & 40.6 & 52.5 & 80.5 & 70.7 & 71.7 & 124.9 \\
\hline Goods and services & 87.5 & 85.4 & 139.2 & 154.2 & 116.6 & 142.7 \\
\hline Interest payments & 1.2 & 0.8 & 2.5 & 3.4 & 1.5 & 13.4 \\
\hline Transfers and subsidies & 70.2 & 75.9 & 169.7 & 117.0 & 153.3 & 153.3 \\
\hline Other current expenditure & 0.0 & 0.0 & 0.0 & 0.0 & 0.0 & 0.0 \\
\hline Capital expenditure & 667.6 & 928.5 & $1,391.5$ & $2,482.3$ & $1,531.9$ & $1,531.9$ \\
\hline Net lending & 0.0 & 0.0 & 0.0 & 0.0 & 0.0 & 0.0 \\
\hline Domestic arrears payments ${ }^{2}$ & 2.6 & 9.1 & 0.0 & 0.0 & 0.0 & 0.0 \\
\hline Overall balance & $1,177.4$ & $1,156.4$ & $1,268.3$ & -459.4 & -111.9 & 55.4 \\
\hline Total financing & $-1,177.4$ & $-1,156.4$ & $-1,268.3$ & 459.4 & 111.9 & -55.4 \\
\hline Foreign financing & -49.8 & -18.7 & 0.0 & 237.5 & 237.6 & 237.5 \\
\hline Budget support loans & 0.0 & 0.0 & 0.0 & 0.0 & 0.0 & 0.0 \\
\hline Loans & 0.0 & 0.0 & 0.0 & 240.0 & 240.0 & 240.0 \\
\hline Amortization (-) & -49.8 & -9.6 & 0.0 & -2.5 & -2.4 & -2.5 \\
\hline Exceptional financing & 0.0 & -9.1 & 0.0 & 0.0 & 0.0 & 0.0 \\
\hline Domestic financing & -953.0 & -929.5 & -183.5 & 167.2 & -125.7 & -292.9 \\
\hline Change in government deposits abroad (- =increase) & -626.4 & -759.5 & 363.8 & -733.3 & 0.0 & 0.0 \\
\hline Government deposits outside BEAC (- =increase) & -533.6 & -659.9 & 363.8 & -733.3 & 0.0 & 0.0 \\
\hline Gepetrol/Sonagas deposits abroad (- =increase) & -92.8 & -99.6 & 0.0 & 0.0 & 0.0 & 0.0 \\
\hline Other Domestic Financing & -326.6 & -170.0 & -547.3 & 900.5 & -125.7 & -292.9 \\
\hline Monetary sector & -326.6 & -170.0 & -547.3 & 900.5 & -125.7 & -292.9 \\
\hline Deposits at BEAC & -326.6 & -170.0 & -547.3 & 900.5 & -125.7 & -292.9 \\
\hline Deposits at domestic banks & 0.0 & 0.0 & 0.0 & 0.0 & 0.0 & 0.0 \\
\hline Net acquisition of non-financial assets ${ }^{3}$ & -127.7 & -90.3 & $-1,084.8$ & 0.0 & 0.0 & 0.0 \\
\hline Errors and omissions/financing gap ${ }^{4}$ & -46.9 & -117.8 & 0.0 & 54.7 & 0.0 & 0.0 \\
\hline \multicolumn{7}{|l|}{ Memorandum items: } \\
\hline Overall balance & $1,177.4$ & $1,156.4$ & $1,268.3$ & -459.4 & -111.9 & 55.4 \\
\hline percent of GDP & 23.4 & 19.2 & 15.4 & -8.0 & -1.6 & 0.8 \\
\hline Non oil primary balance ${ }^{5}$ & -580.1 & -784.9 & $-1,412.2$ & $-2,425.1$ & $-1,494.6$ & $-1,586.5$ \\
\hline percent of non-oil GDP & -54.6 & -49.7 & -67.2 & -102.0 & -50.6 & -53.7 \\
\hline Total Government Savings & $1,821.7$ & $2,632.3$ & $3,560.3$ & $3,335.8$ & $3,461.5$ & $3,628.7$ \\
\hline Of which: Government treasury accounts abroad & 587.6 & $1,249.9$ & $1,687.9$ & $2,363.9$ & $2,363.9$ & $2,363.9$ \\
\hline Nominal GDP & $5,021.4$ & $6,026.8$ & $8,250.2$ & $5,771.2$ & $6,937.1$ & $6,937.1$ \\
\hline Nominal non-oil GDP & $1,062.3$ & $1,577.9$ & $2,102.1$ & $2,377.3$ & $2,952.5$ & $2,952.5$ \\
\hline
\end{tabular}

Sources: Data provided by the Equatoguinean authorities; and staff estimates and projections.

${ }^{1}$ The VAT $w$ as legislated in early 2005 ; previously this $w$ as a sales tax.

${ }^{2}$ Related to the crash of the banking system during the early 1980 s.

${ }^{3}$ Includes all equity purchases of the government.

${ }^{4}$ Errors and omissions financing gap for 2007 is partly influenced by lack of data on deposits abroad for that year.

${ }^{5}$ Equal to the overall balance excluding grants minus hydrocarbons sector corporate income tax and non tax revenue plus hydrocarbons revenue generated in projects, minus interest on saving funds plus interest expenditure.the secondary LNG, LPG and methanol production and purchase of share in hydrocarbons. 
Table 4b. Equatorial Guinea: Summary of Central Government Financial Operations, 2006-10 (percent of GDP, unless otherw ise specified)

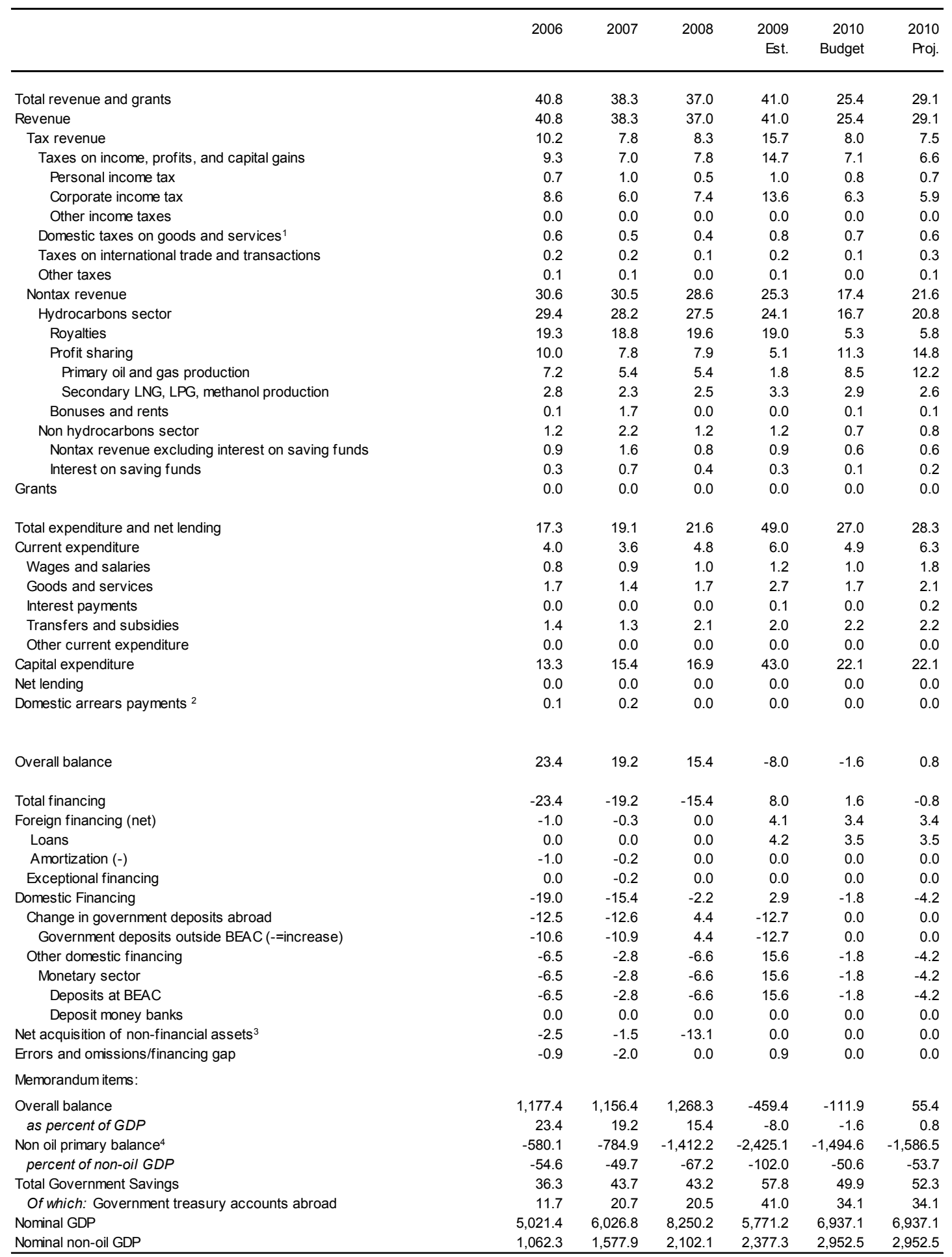

Sources: Data provided by the Equatoguinean authorities; and staff estimates and projections.

${ }^{1}$ The VAT $w$ as legislated in early 2005; previously this $w$ as a sales tax.

${ }^{2}$ Related to the crash of the banking system during the early $1980 \mathrm{~s}$.

${ }^{3}$ Includes all equity purchases of the government; in 2008 this is mainly related to the $\$ 2.2$ billion purchase of Devon Energy's assets in Equatorial Guinea.

${ }^{4}$ Equal to the overall balance excluding grants minus hydrocarbons sector corporate income tax and non tax revenue plus hydrocarbons revenue generated in the secondary LNG, LPG and methanol production and purchase of share in hydrocarbon projects, minus interest on saving funds plus interest expenditure. 
Table 5a. Equatorial Guinea: Monetary Survey, 2006-10

(Billions of CFA francs, unless otherwise specified; end of period)

\begin{tabular}{|c|c|c|c|c|c|c|}
\hline & \multirow{2}{*}{$\begin{array}{l}2006 \\
\text { Dec. }\end{array}$} & \multirow{2}{*}{$\begin{array}{l}2007 \\
\text { Dec. }\end{array}$} & \multirow{2}{*}{$\frac{2008}{\text { Dec. }}$} & \multicolumn{2}{|c|}{2009} & \multirow{2}{*}{$\begin{array}{l}2010 \\
\text { Dec. } \\
\text { Proj. }\end{array}$} \\
\hline & & & & Sep. & $\begin{array}{l}\text { Dec. } \\
\text { Est. }\end{array}$ & \\
\hline $\begin{array}{l}\text { Net foreign assets } \\
\text { (millions of U.S. dollars) }\end{array}$ & $\begin{array}{l}1,573.9 \\
3,160.1\end{array}$ & $\begin{array}{l}1,804.3 \\
4,049.2\end{array}$ & $\begin{array}{l}2,241.8 \\
4,756.3\end{array}$ & $\begin{array}{l}1,713.0 \\
3,823.9\end{array}$ & $\begin{array}{l}1,505.7 \\
3,306.8\end{array}$ & $\begin{array}{l}2,002.5 \\
4,484.3\end{array}$ \\
\hline Net domestic assets & $-1,255.4$ & $-1,322.4$ & $-1,655.7$ & $-1,022.6$ & -717.0 & -898.0 \\
\hline Domestic credit & $-1,224.6$ & $-1,340.4$ & $-1,687.0$ & -778.4 & -752.1 & -942.8 \\
\hline Claims on government (net) & $-1,354.0$ & $-1,524.0$ & $-2,071.3$ & $-1,096.9$ & $-1,170.8$ & $-1,463.7$ \\
\hline Claims on non-government & 129.5 & 183.7 & 384.3 & 318.5 & 418.7 & 520.9 \\
\hline Other items (net) & -30.8 & 18.0 & 31.3 & -244.2 & 35.1 & 44.8 \\
\hline Broad money (M2) & 318.5 & 449.9 & 585.4 & 689.6 & 768.8 & 872.4 \\
\hline Currency & 68.2 & 80.9 & 90.1 & 106.0 & 98.1 & 110.7 \\
\hline Deposits & 250.3 & 369.0 & 495.3 & 583.6 & 670.7 & 761.6 \\
\hline \multicolumn{7}{|l|}{ Memorandum items: } \\
\hline CPI inflation (average annual) & 4.5 & 2.8 & 4.3 & $\ldots$ & 7.1 & 7.1 \\
\hline Broad money (M2) & 14.1 & 41.3 & 30.1 & -12.5 & 31.3 & 13.5 \\
\hline Reserve money (RM) & 5.4 & 28.1 & 5.1 & -6.1 & 64.2 & 19.8 \\
\hline Credit to the private sector & 34.8 & 40.5 & 15.0 & 0.3 & 0.1 & 11.6 \\
\hline Credit to the private sector (percent of non-oil GDP, excluding oil derivatives) & 17.6 & 19.8 & 33.6 & $\ldots$ & 22.5 & 19.4 \\
\hline Broad money (percent of overall GDP) & 6.3 & 7.5 & 7.1 & $\ldots$ & 13.3 & 12.6 \\
\hline Velocity (overall GDP/end-of-period M2) & 15.8 & 13.4 & 14.1 & $\ldots$ & 7.5 & 8.0 \\
\hline Velocity (non-oil GDP excluding oil derivatives/end-of-period M2) & 2.2 & 2.0 & 1.8 & $\ldots$ & 2.1 & 2.4 \\
\hline Reserve money multiplier (M2/RM) & 1.1 & 1.2 & 1.8 & 0.9 & 1.4 & 1.4 \\
\hline Currency/M2 ratio & 0.2 & 0.2 & 0.2 & 0.2 & 0.1 & 0.1 \\
\hline Lending rate ${ }^{1}$ & 15.0 & 15.0 & 15.0 & n.a. & $\cdots$ & $\cdots$ \\
\hline Deposit rate & 4.3 & 4.3 & 3.3 & n.a. & $\ldots$ & $\ldots$ \\
\hline
\end{tabular}

Sources: BEAC and staff estimates and projections.

' Lending rates are not regulated by BEAC, beginning July 2008. 
Table 5b. Equatorial Guinea: Central Bank and Commercial Banks, 2006-10

(Billions of CFA francs, unless otherwise specified; end of period)

\begin{tabular}{|c|c|c|c|c|c|c|}
\hline & 2006 & 2007 & 2008 & \multicolumn{2}{|c|}{2009} & 2010 \\
\hline & Dec. & Dec. & Dec. & $\begin{array}{l}\text { Sep. } \\
\text { Prel. }\end{array}$ & $\begin{array}{l}\text { Dec. } \\
\text { Est. }\end{array}$ & $\begin{array}{l}\text { Dec. } \\
\text { Proj. }\end{array}$ \\
\hline \multicolumn{7}{|l|}{ Central Bank } \\
\hline $\begin{array}{l}\text { Net foreign assets } \\
\quad \text { (millions of U.S. dollars) }\end{array}$ & $\begin{array}{l}1,523.0 \\
3,057.9\end{array}$ & $\begin{array}{l}1,713.2 \\
3,844.7\end{array}$ & $\begin{array}{l}2,086.4 \\
4,426.6\end{array}$ & $\begin{array}{l}1,684.7 \\
3,760.7\end{array}$ & $\begin{array}{l}1,393.6 \\
3,060.7\end{array}$ & $\begin{array}{l}1,791.9 \\
4,012.6\end{array}$ \\
\hline $\begin{array}{l}\text { Net domestic assets } \\
\text { Claims on government (net) } \\
\text { Claims on commercial banks (net) } \\
\text { Claims on rest of the economy } \\
\text { Other items (net) }\end{array}$ & $\begin{array}{r}-1,240.8 \\
-1,243.0 \\
0.0 \\
0.0 \\
2.3\end{array}$ & $\begin{array}{r}-1,351.6 \\
-1,401.6 \\
0.0 \\
0.0 \\
49.9\end{array}$ & $\begin{array}{r}-1,762.8 \\
-1,807.6 \\
0.0 \\
0.0 \\
44.8\end{array}$ & $\begin{array}{r}-936.7 \\
-923.8 \\
0.0 \\
0.0 \\
-12.9\end{array}$ & $\begin{array}{r}-862.3 \\
-907.1 \\
0.0 \\
0.0 \\
44.8\end{array}$ & $\begin{array}{r}-1,155.2 \\
-1,200.0 \\
0.0 \\
0.0 \\
44.8\end{array}$ \\
\hline $\begin{array}{l}\text { Reserve money } \\
\text { Currency outside banks } \\
\text { Bank reserves } \\
\text { Cash } \\
\text { Deposits } \\
\text { Nonbank deposits }\end{array}$ & $\begin{array}{r}282.3 \\
68.2 \\
213.4 \\
11.0 \\
202.3 \\
0.7\end{array}$ & $\begin{array}{r}361.5 \\
80.9 \\
279.8 \\
13.1 \\
266.8 \\
0.8\end{array}$ & $\begin{array}{r}323.6 \\
90.1 \\
232.8 \\
14.6 \\
218.2 \\
0.7\end{array}$ & $\begin{array}{r}748.0 \\
106.0 \\
641.3 \\
13.6 \\
627.7 \\
0.7\end{array}$ & $\begin{array}{r}531.4 \\
98.1 \\
432.5 \\
14.2 \\
418.3 \\
0.7\end{array}$ & $\begin{array}{r}636.7 \\
110.7 \\
525.3 \\
14.6 \\
510.7 \\
0.7\end{array}$ \\
\hline \multicolumn{7}{|l|}{ Deposit money banks } \\
\hline $\begin{array}{l}\text { Net foreign assets } \\
\text { (millions of U.S. dollars) }\end{array}$ & $\begin{array}{r}50.9 \\
102.2\end{array}$ & $\begin{array}{r}91.1 \\
204.5\end{array}$ & $\begin{array}{l}155.4 \\
329.7\end{array}$ & $\begin{array}{l}28.3 \\
63.1\end{array}$ & $\begin{array}{l}112.1 \\
246.2\end{array}$ & $\begin{array}{l}210.6 \\
471.7\end{array}$ \\
\hline Net domestic assets & 198.7 & 277.9 & 339.9 & 555.3 & 647.8 & 832.4 \\
\hline $\begin{array}{l}\text { Reserves } \\
\text { Cash }\end{array}$ & $\begin{array}{r}213.4 \\
11.0\end{array}$ & $\begin{array}{r}248.6 \\
13.1\end{array}$ & $\begin{array}{r}232.8 \\
14.6\end{array}$ & $\begin{array}{r}641.3 \\
13.6\end{array}$ & $\begin{array}{r}432.5 \\
14.2\end{array}$ & $\begin{array}{r}525.3 \\
14.6\end{array}$ \\
\hline Deposits with central bank & 202.3 & 235.6 & 218.2 & 627.7 & 418.3 & 510.7 \\
\hline Required reserves & 37.0 & 64.4 & 86.6 & 99.1 & 105.9 & 119.4 \\
\hline Excess reserves & 165.3 & 171.1 & 131.6 & 528.6 & 312.5 & 391.2 \\
\hline Domestic credit & 18.4 & 61.2 & 120.6 & 145.4 & 224.9 & 307.1 \\
\hline Claims on central bank (net) & 0.0 & 0.0 & 0.0 & 0.0 & 0.0 & 0.0 \\
\hline Claims on government (net) & -111.0 & -122.5 & -263.7 & -173.1 & -193.7 & -213.7 \\
\hline Claims & 3.7 & 1.7 & 2.5 & 1.8 & 2.7 & 3.0 \\
\hline Deposits & -114.8 & -124.2 & -266.2 & -174.8 & -196.5 & -216.7 \\
\hline Claims on non-government & 129.5 & 183.7 & 384.3 & 318.5 & 418.7 & 520.9 \\
\hline Public enterprises & 4.9 & 8.7 & 22.2 & 18.2 & 56.1 & 116.4 \\
\hline Private sector & 124.5 & 174.9 & 362.2 & 300.3 & 362.5 & 404.5 \\
\hline Other items (net) & -33.1 & -31.9 & -13.5 & -231.4 & -9.7 & 0.0 \\
\hline Deposit liabilities to nonbank residents & 250.3 & 369.0 & 495.3 & 583.6 & 670.7 & 761.6 \\
\hline
\end{tabular}

Sources: Data provided by Equatoguinean authorities; and staff estimates and projections. 
Table 7. Equatorial Guinea: Selected Medium-Term Economic and Financial Indicators, 2009-15

\begin{tabular}{|c|c|c|c|c|c|c|c|}
\hline & 2009 & 2010 & 2011 & 2012 & 2013 & 2014 & 2015 \\
\hline & Est. & Proj. & Proj. & & & & \\
\hline & \multicolumn{7}{|c|}{ (Annual percentage change, unless otherw ise specified) } \\
\hline \multicolumn{8}{|l|}{ Production, prices, and money } \\
\hline Real GDP & 5.3 & 0.9 & 2.1 & 1.5 & 2.7 & 0.8 & 0.7 \\
\hline Oil and gas GDP (excluding hydrocarbons secondary production) & -6.6 & -6.3 & -1.8 & -3.5 & -12.0 & -9.7 & -4.3 \\
\hline Non-oil GDP (including hydrocarbons secondary production) & 27.6 & 10.8 & 6.7 & 6.9 & 16.9 & 8.5 & 3.8 \\
\hline GDP deflator & -33.6 & 19.1 & 9.3 & 4.6 & 1.8 & 1.7 & 3.2 \\
\hline Oil and gas GDP (excluding hydrocarbons secondary production) & -40.9 & 25.3 & 11.8 & 4.4 & 3.9 & 0.9 & 0.9 \\
\hline Non-oil GDP (including hydrocarbons secondary production) & -11.3 & 12.1 & 6.9 & 5.9 & 2.5 & 3.9 & 5.2 \\
\hline Hydrocarbons production (thousands of boe per day) & 461.9 & 434.5 & 430.3 & 419.6 & 447.4 & 447.3 & 434.6 \\
\hline Oil and gas primary production 1 & 318.7 & 292.1 & 285.2 & 271.9 & 228.2 & 197.1 & 184.6 \\
\hline Hydrocarbons secondary production ${ }^{2}$ & 143.2 & 142.4 & 145.1 & 147.7 & 219.1 & 250.2 & 250.0 \\
\hline Oil price (U.S. dollars per barrel) ${ }^{3}$ & 58.5 & 73.0 & 79.0 & 81.8 & 83.5 & 84.5 & 85.5 \\
\hline Consumer prices (annual average) & 7.1 & 7.1 & 6.6 & 6.4 & 6.1 & 6.1 & 6.1 \\
\hline Consumer prices (end of period) & 7.7 & 6.9 & 6.4 & 6.3 & 6.0 & 5.6 & 5.5 \\
\hline Broad money & 31.3 & 13.5 & 26.7 & 16.5 & 14.4 & 13.6 & 12.8 \\
\hline \multicolumn{8}{|l|}{ External sector } \\
\hline Exports, f.o.b. & -41.3 & 15.1 & 5.9 & -0.1 & -2.6 & -4.9 & -3.2 \\
\hline Hydrocarbons exports & -41.6 & 15.2 & 5.9 & -0.3 & -2.7 & -5.1 & -3.3 \\
\hline Oil primary exports & -44.6 & 14.0 & 5.6 & -1.5 & -14.8 & -13.2 & -5.6 \\
\hline Hydrocarbons secondary exports & -27.2 & 19.6 & 6.9 & 4.1 & 37.6 & 11.6 & 0.2 \\
\hline Imports, f.o.b. & 34.5 & -26.9 & 27.4 & -1.8 & -8.5 & -18.7 & -0.6 \\
\hline Non-oil sector imports & 47.1 & -29.4 & 31.1 & 3.2 & -9.2 & -19.5 & 0.3 \\
\hline Terms of trade & -25.1 & 13.3 & 5.2 & 1.9 & -0.1 & -1.6 & -1.2 \\
\hline \multicolumn{8}{|l|}{ Government finance } \\
\hline Revenue and grants & -22.4 & -14.6 & 6.0 & -4.2 & -10.8 & -0.3 & -2.3 \\
\hline \multirow[t]{2}{*}{ Total expenditure and net lending } & 58.5 & -30.5 & 34.2 & 5.6 & -8.3 & -1.9 & -1.1 \\
\hline & \multicolumn{7}{|c|}{ (Percent of GDP, unless otherw ise specified) } \\
\hline \multicolumn{8}{|l|}{ Investment and savings } \\
\hline Gross investment & 46.7 & 29.2 & 34.9 & 26.8 & 24.3 & 20.9 & 18.9 \\
\hline Public & 43.0 & 22.1 & 27.0 & 25.5 & 20.5 & 18.5 & 16.5 \\
\hline Private & 3.6 & 7.1 & 7.9 & 1.3 & 3.8 & 2.5 & 2.4 \\
\hline Gross national savings & 30.7 & 24.6 & 22.5 & 16.7 & 15.4 & 12.9 & 11.2 \\
\hline \multicolumn{8}{|l|}{ Government finance } \\
\hline Revenue and grants & 41.0 & 29.1 & 27.7 & 25.0 & 21.3 & 20.7 & 19.5 \\
\hline Hydrocarbons revenue & 37.2 & 26.3 & 24.9 & 22.1 & 18.4 & 16.6 & 15.4 \\
\hline Expenditure and net lending & 49.0 & 28.3 & 34.1 & 33.9 & 29.7 & 28.4 & 27.0 \\
\hline Overall balance after grants (cash basis) & -8.0 & 0.8 & -6.4 & -8.9 & -8.4 & -7.7 & -7.5 \\
\hline Non-oil primary balance (cash basis, percent of non-oil GDP) ${ }^{4}$ & -102.0 & -53.7 & -65.9 & -61.0 & -41.7 & -35.2 & -31.5 \\
\hline Gross government savings (billions of CFAs) & 3,336 & 3,629 & 3,386 & 2,797 & 1,914 & 985 & 40 \\
\hline \multicolumn{8}{|l|}{ External sector } \\
\hline Current account balance (including official transfers; deficit -) & -16.0 & -4.6 & -12.4 & -10.1 & -8.9 & -8.1 & -7.6 \\
\hline Outstanding medium- and long-term public debt & 4.9 & 7.4 & 9.9 & 12.1 & 10.7 & 8.6 & 5.5 \\
\hline Debt service-to-exports ratio (percent) & 0.2 & 0.4 & 0.7 & 2.7 & 4.8 & 6.9 & 6.9 \\
\hline External debt service/government revenue (percent) & 0.8 & 1.7 & 3.1 & 13.4 & 26.5 & 36.0 & 35.8 \\
\hline \multicolumn{8}{|c|}{ (Millions of U.S. dollars, unless otherw ise specified) } \\
\hline \multicolumn{8}{|l|}{ External Sector } \\
\hline Exports, f.o.b. & 8,495 & 9,781 & 10,362 & 10,347 & 10,082 & 9,590 & 9,285 \\
\hline Hydrocarbons exports & 8,386 & 9,661 & 10,230 & 10,201 & 9,926 & 9,422 & 9,107 \\
\hline Oil primary exports & 6,612 & 7,539 & 7,962 & 7,840 & 6,677 & 5,797 & 5,475 \\
\hline Hydrocarbons secondary exports & 1,774 & 2,122 & 2,269 & 2,361 & 3,249 & 3,625 & 3,631 \\
\hline Imports, f.o.b. & $-5,258$ & $-3,845$ & $-4,899$ & $-4,808$ & $-4,401$ & $-3,576$ & $-3,555$ \\
\hline Current account balance (deficit -) & $-1,950$ & -714 & $-2,141$ & $-1,837$ & $-1,694$ & $-1,569$ & $-1,540$ \\
\hline Overall balance of payments & $-1,467$ & 894 & -83 & -143 & -332 & -312 & -433 \\
\hline Outstanding medium- and long-term public debt & 620 & 1,153 & 1,715 & 2,200 & 2,025 & 1,666 & 1,108 \\
\hline Gross official foreign assets & 8,463 & 9,417 & 8,906 & 7,801 & 6,057 & 4,266 & 2,444 \\
\hline Reserve assets at the BEAC & 3,146 & 4,100 & 3,954 & 3,787 & 3,427 & 3,129 & 2,697 \\
\hline Government bank deposits abroad & 5,317 & 5,317 & 4,951 & 4,014 & 2,629 & 1,136 & -252 \\
\hline Gross official reserves of BEAC (millions of U.S. dollars) & $\ldots$ & $\ldots$ & $\ldots$ & $\ldots$ & $\ldots$ & $\ldots$ & $\ldots$ \\
\hline Gross official reserves of BEAC (months of next year's imports ) & $\ldots$ & $\ldots$ & $\ldots$ & $\ldots$ & $\ldots$ & $\ldots$ & $\ldots$ \\
\hline Nominal GDP (billions of CFA francs) & 5,771 & 6,937 & 7,745 & 8,222 & 8,597 & 8,817 & 9,163 \\
\hline Non-oil GDP (including hydrocarbons secondary production) & 2,377 & 2,952 & 3,367 & 3,814 & 4,569 & 5,149 & 5,624 \\
\hline
\end{tabular}

Sources: Data provided by the Equatoguinean authorities; and staff estimates and projections.

${ }^{1}$ Including oil equivalent of gas.

${ }^{2}$ Including oil equivalent of LNG, LPG, butane, propane, and methanol.

${ }^{3}$ The price of oil is the average of three spot prices: dated Brent, West Texas Intermediate, and Dubai Fateh; and includes a discount for quality.

${ }^{4}$ Excluding oil revenues, oil-related expenditures, and interest earned and paid. 
Table 8. Equatorial Guinea: Balance of Payments, 2010-15 1

(Millions of U.S. dollars, unless otherw ise specified)

\begin{tabular}{|c|c|c|c|c|c|c|}
\hline & $\begin{array}{c}2010 \\
\text { Proj. }\end{array}$ & $\begin{array}{r}2011 \\
\text { Proj. }\end{array}$ & $\begin{array}{c}2012 \\
\text { Proj. }\end{array}$ & $\begin{array}{r}2013 \\
\text { Proj. }\end{array}$ & $\begin{array}{r}2014 \\
\text { Proj. }\end{array}$ & $\begin{array}{r}2015 \\
\text { Proj. }\end{array}$ \\
\hline Current account & -714 & $-2,141$ & $-1,837$ & $-1,694$ & $-1,569$ & $-1,540$ \\
\hline Trade balance & 5,936 & 5,463 & 5,538 & 5,681 & 6,015 & 5,730 \\
\hline Exports of goods, f.o.b. & 9,781 & 10,362 & 10,347 & 10,082 & 9,590 & 9,285 \\
\hline Hydrocarbons exports & 9,661 & 10,230 & 10,201 & 9,926 & 9,422 & 9,107 \\
\hline Imports of goods, f.o.b. & $-3,845$ & $-4,899$ & $-4,808$ & $-4,401$ & $-3,576$ & $-3,555$ \\
\hline Petroleum sector & -548 & -575 & -345 & -349 & -314 & -283 \\
\hline Petroleum products & -212 & -223 & -245 & -257 & -270 & -284 \\
\hline Public sector equipment & $-2,408$ & $-3,272$ & $-3,256$ & $-2,718$ & $-1,797$ & $-1,665$ \\
\hline Other ${ }^{2}$ & -677 & -828 & -962 & $-1,076$ & $-1,194$ & $-1,323$ \\
\hline Services (net) & $-1,598$ & $-1,874$ & $-1,878$ & $-1,856$ & $-2,163$ & $-2,038$ \\
\hline Income (net) ${ }^{3}$ & $-4,925$ & $-5,579$ & $-5,320$ & $-5,324$ & $-5,206$ & $-4,997$ \\
\hline Current transfers & -127 & -152 & -178 & -196 & -215 & -236 \\
\hline Capital and financial account & 1,608 & 2,058 & 1,695 & 1,362 & 1,257 & 1,108 \\
\hline Capital account & 0 & 0 & 0 & 0 & 0 & 0 \\
\hline Financial account & 1,608 & 2,058 & 1,695 & 1,362 & 1,257 & 1,108 \\
\hline Direct investment & 1,369 & 1,438 & 863 & 776 & 699 & 629 \\
\hline Portfolio investment (net) & 0 & 0 & 0 & 0 & 0 & 0 \\
\hline Other investment (net) & 239 & 621 & 832 & 586 & 558 & 479 \\
\hline Medium - and long-term transactions & 532 & 560 & 317 & -355 & -549 & -549 \\
\hline General government & 533 & 562 & 316 & -359 & -558 & -563 \\
\hline Of which: Amortization & -6 & -5 & -174 & -359 & -558 & -563 \\
\hline Banks & 0 & 0 & 0 & 0 & 0 & 0 \\
\hline Other sectors & -2 & -2 & 1 & 5 & 9 & 14 \\
\hline Short-term transactions & -293 & 61 & 516 & 940 & 1,107 & 1,028 \\
\hline General government 4,5 & 0 & 366 & 937 & 1,385 & 1,493 & 1,389 \\
\hline Banks & -221 & -129 & -103 & -104 & -111 & -118 \\
\hline Other sectors & -71 & -177 & -319 & -341 & -275 & -242 \\
\hline Errors and omissions & 0 & 0 & 0 & 0 & 0 & 0 \\
\hline Overall balance & 894 & -83 & -143 & -332 & -312 & -433 \\
\hline Financing & -894 & 83 & 143 & 332 & 312 & 433 \\
\hline Change in net international reserves ${ }^{6}$ (increase -) & -894 & 83 & 143 & 332 & 312 & 433 \\
\hline \multicolumn{7}{|l|}{ Memorandum items: } \\
\hline Gross official foreign assets & 9,417 & 8,906 & 7,801 & 6,057 & 4,266 & 2,444 \\
\hline Reserve assets at BEAC & 4,100 & 3,954 & 3,787 & 3,427 & 3,129 & 2,697 \\
\hline Of which: Government reserve assets at BEAC & 2,832 & 2,641 & 2,255 & 1,678 & 1,128 & 433 \\
\hline Government bank deposits outside BEAC & 5,294 & 4,901 & 3,935 & 2,526 & 1,043 & -345 \\
\hline Gross government savings & 8,126 & 7,541 & 6,190 & 4,204 & 2,171 & 88 \\
\hline Current account balance (percent of GDP; deficit -) & -4.6 & -12.4 & -10.1 & -8.9 & -8.1 & -7.6 \\
\hline Overall balance (percent of GDP; deficit -) & 5.7 & -0.5 & -0.8 & -1.8 & -1.6 & -2.1 \\
\hline Grow th of oil exports, including petroleum derivatives (percent) & 15.2 & 5.9 & -0.3 & -2.7 & -5.1 & -3.3 \\
\hline Grow th of non-oil exports, excluding petroleum derivatives (percent) & 10.7 & 9.7 & 10.5 & 7.6 & 7.6 & 6.1 \\
\hline Grow th of other imports ${ }^{2}$ (percent) & 22.7 & 22.4 & 16.2 & 11.9 & 11.0 & 10.8 \\
\hline
\end{tabular}

Sources: Equatoguinean authorities; and staff estimates and projections.

${ }^{1}$ The BOP data in this table are not compiled in accordance w ith the IMF's Balance of Payments Manual, fifth edition. The historic data have not been derived from customs' and bank records' data, but from estimates of BEAC. Fund staff have made ad hoc adjustments to the data.

2 Including private sector consumption and investment imports.

${ }^{3}$ Including investment income of oil companies, $w$ hich includes reinvested earnings ( $w$ ith an offsetting entry in foreign direct investment)

${ }^{4}$ Includes purchase of Devon's share of oil fields in 2008 by Equatorial Guinea.

${ }^{5}$ Since 2000 , entries represent changes in government deposits in commercial banks abroad.

${ }^{6}$ Consists only of items on the balance sheet of the BEAC (i.e., excluding government bank deposits abroad). 
Table 9a. Equatorial Guinea: Summary of Central Government Financial Operations, 2010-15 (Billions of CFA francs, unless otherw ise specified)

\begin{tabular}{|c|c|c|c|c|c|c|}
\hline & $\begin{array}{c}2010 \\
\text { Proj. }\end{array}$ & $\begin{array}{r}2011 \\
\text { Proj. }\end{array}$ & $\begin{array}{r}2012 \\
\text { Proj. }\end{array}$ & $\begin{array}{c}2013 \\
\text { Proj. }\end{array}$ & $\begin{array}{c}2014 \\
\text { Proj. }\end{array}$ & $\begin{array}{r}2015 \\
\text { Proj. }\end{array}$ \\
\hline Total revenue and grants & $2,021.6$ & $2,143.3$ & $2,053.5$ & $1,832.5$ & $1,827.3$ & $1,785.9$ \\
\hline Revenue & $2,021.6$ & $2,143.3$ & $2,053.5$ & $1,832.5$ & $1,827.3$ & $1,785.9$ \\
\hline Tax revenue & 523.6 & 532.2 & 541.6 & 395.3 & 375.5 & 377.8 \\
\hline Taxes on income, profits, and capital gains & 456.2 & 455.6 & 455.7 & 300.5 & 271.3 & 263.6 \\
\hline Personal income tax & 50.2 & 50.8 & 51.6 & 37.7 & 35.8 & 35.9 \\
\hline Corporate income tax & 406.0 & 404.8 & 404.1 & 262.8 & 235.5 & 227.6 \\
\hline Other income taxes & 0.0 & 0.0 & 0.0 & 0.0 & 0.0 & 0.0 \\
\hline Domestic taxes on goods and services ${ }^{1}$ & 43.8 & 48.2 & 53.2 & 58.3 & 63.8 & 69.6 \\
\hline Taxes on international trade and transactions & 19.4 & 23.7 & 27.6 & 30.8 & 34.2 & 37.9 \\
\hline Other taxes & 4.3 & 4.7 & 5.2 & 5.7 & 6.2 & 6.8 \\
\hline Nontax revenue & $1,498.0$ & $1,611.1$ & $1,511.8$ & $1,437.2$ & $1,451.8$ & $1,408.1$ \\
\hline Hydrocarbons sector & $1,441.3$ & $1,550.8$ & $1,442.7$ & $1,352.4$ & $1,268.3$ & $1,221.6$ \\
\hline Royalties & 402.0 & 428.9 & 392.1 & 423.9 & 368.0 & 347.6 \\
\hline Profit sharing & $1,029.7$ & $1,112.4$ & $1,041.1$ & 919.0 & 889.7 & 864.1 \\
\hline Bonuses and rents & 9.5 & 9.5 & 9.5 & 9.5 & 10.5 & 9.9 \\
\hline Non hydrocarbons sector & 56.7 & 60.3 & 69.2 & 84.8 & 183.5 & 186.5 \\
\hline Nontax revenue excluding interest on saving funds & 42.5 & 42.5 & 46.9 & 51.4 & 56.2 & 61.3 \\
\hline Interest on saving funds & 14.3 & 17.8 & 22.3 & 33.4 & 127.3 & 125.1 \\
\hline Grants & 0.0 & 0.0 & 0.0 & 0.0 & 0.0 & 0.0 \\
\hline Total expenditure and net lending & $1,966.2$ & $2,638.0$ & $2,784.5$ & $2,552.2$ & $2,503.8$ & $2,475.1$ \\
\hline Current expenditure & 434.3 & 545.0 & 689.5 & 791.5 & 874.4 & 965.0 \\
\hline Wages and salaries & 124.9 & 170.4 & 240.8 & 275.5 & 312.9 & 353.0 \\
\hline Goods and services & 142.7 & 168.1 & 196.6 & 224.2 & 253.0 & 283.2 \\
\hline Interest payments & 13.4 & 28.6 & 46.1 & 57.8 & 45.4 & 35.2 \\
\hline Transfers and subsidies & 153.3 & 177.9 & 206.0 & 234.0 & 263.1 & 293.6 \\
\hline Capital expenditure & $1,531.9$ & $2,093.0$ & $2,095.0$ & $1,760.7$ & $1,629.4$ & $1,510.0$ \\
\hline Net lending & 0.0 & 0.0 & 0.0 & 0.0 & 0.0 & 0.0 \\
\hline Domestic arrears payments & 0.0 & 0.0 & 0.0 & 0.0 & 0.0 & 0.0 \\
\hline Overall balance & 55.4 & -494.7 & -731.0 & -719.7 & -676.6 & -689.1 \\
\hline Total financing & -55.4 & 494.7 & 731.0 & 719.7 & 676.6 & 689.1 \\
\hline Foreign financing (net) & 237.5 & 251.6 & 142.1 & -162.9 & -253.1 & -255.3 \\
\hline Loans & 240.0 & 253.9 & 220.7 & 0.0 & 0.0 & 0.0 \\
\hline Amortization (-) & -2.5 & -2.2 & -78.6 & -162.9 & -253.1 & -255.3 \\
\hline Domestic Financing & -292.9 & 243.1 & 588.9 & 882.6 & 929.7 & 944.5 \\
\hline Change in government deposits abroad & 0.0 & 163.8 & 422.1 & 627.9 & 676.9 & 629.6 \\
\hline Treasury deposits abroad (-=increase) & 0.0 & 163.8 & 422.1 & 627.9 & 676.9 & 629.6 \\
\hline Gepetrol/Sonagas deposits abroad (-=increase) & 0.0 & 0.0 & 0.0 & 0.0 & 0.0 & 0.0 \\
\hline Other domestic financing & -292.9 & 79.2 & 166.7 & 254.7 & 252.8 & 314.8 \\
\hline Monetary sector & -292.9 & 79.2 & 166.7 & 254.7 & 252.8 & 314.8 \\
\hline Deposits at BEAC & -292.9 & 79.2 & 166.7 & 254.7 & 252.8 & 314.8 \\
\hline Net acquisitions of non-financial assets ${ }^{2}$ & 0.0 & 0.0 & 0.0 & 0.0 & 0.0 & 0.0 \\
\hline Errors and omissions/financing gap & 0.0 & 0.0 & 0.0 & 0.0 & 0.0 & 0.0 \\
\hline \multicolumn{7}{|l|}{ Memorandum items: } \\
\hline Overall balance & 55.4 & -494.7 & -731.0 & -719.7 & -676.6 & -689.1 \\
\hline percent of GDP & 0.8 & -6.4 & -8.9 & -8.4 & -7.7 & -7.5 \\
\hline Non oil primary balance ${ }^{3}$ & $-1,586.5$ & $-2,220.1$ & $-2,325.8$ & $-1,903.9$ & $-1,810.1$ & $-1,772.2$ \\
\hline percent of non-oil GDP & -53.7 & -65.9 & -61.0 & -41.7 & -35.2 & -31.5 \\
\hline Total Government Savings & $3,628.7$ & $3,385.7$ & $2,796.8$ & $1,914.2$ & 984.5 & 40.0 \\
\hline Of which: Government treasury accounts abroad & $2,363.9$ & $2,200.1$ & $1,778.0$ & $1,150.1$ & 473.1 & -156.5 \\
\hline Nominal GDP & $6,937.1$ & $7,744.6$ & $8,222.1$ & $8,597.1$ & $8,817.3$ & $9,162.7$ \\
\hline Nominal non-oil GDP & $2,952.5$ & $3,367.5$ & $3,813.6$ & $4,568.6$ & $5,149.2$ & $5,623.9$ \\
\hline
\end{tabular}

Sources: Data provided by the Equatoguinean authorities; and staff estimates and projections.

1 The VAT w as legislated in early 2005 ; previously this $w$ as a sales tax.

2 Includes equity purchases of the government.

${ }^{3}$ Equal to the overall balance excluding grants minus hydrocarbons sector corporate income tax and non tax revenue plus hydrocarbons revenue generated in the secondary LNG, LPG and methanol production and purchase of share in hydrocarbons projects, minus interest on saving funds plus interest expenditure. 
Table 9b. Equatorial Guinea: Summary of Central Government Financial Operations, 2010-15 (percent of GDP, unless otherw ise specified)

\begin{tabular}{|c|c|c|c|c|c|c|}
\hline & 2010 & 2011 & 2012 & 2013 & 2014 & 2015 \\
\hline & Proj. & Proj. & Proj. & Proj. & Proj. & Proj. \\
\hline Total revenue and grants & 29.1 & 27.7 & 25.0 & 21.3 & 20.7 & 19.5 \\
\hline Revenue & 29.1 & 27.7 & 25.0 & 21.3 & 20.7 & 19.5 \\
\hline Tax revenue & 7.5 & 6.9 & 6.6 & 4.6 & 4.3 & 4.1 \\
\hline Taxes on income, profits, and capital gains & 6.6 & 5.9 & 5.5 & 3.5 & 3.1 & 2.9 \\
\hline Personal income tax & 0.7 & 0.7 & 0.6 & 0.4 & 0.4 & 0.4 \\
\hline Corporate income tax & 5.9 & 5.2 & 4.9 & 3.1 & 2.7 & 2.5 \\
\hline Other income taxes & 0.0 & 0.0 & 0.0 & 0.0 & 0.0 & 0.0 \\
\hline Domestic taxes on goods and services ${ }^{1}$ & 0.6 & 0.6 & 0.6 & 0.7 & 0.7 & 0.8 \\
\hline Taxes on international trade and transactions & 0.3 & 0.3 & 0.3 & 0.4 & 0.4 & 0.4 \\
\hline Other taxes & 0.1 & 0.1 & 0.1 & 0.1 & 0.1 & 0.1 \\
\hline Nontax revenue & 21.6 & 20.8 & 18.4 & 16.7 & 16.5 & 15.4 \\
\hline Hydrocarbons sector & 20.8 & 20.0 & 17.5 & 15.7 & 14.4 & 13.3 \\
\hline Royalties & 5.8 & 5.5 & 4.8 & 4.9 & 4.2 & 3.8 \\
\hline Profit sharing & 14.8 & 14.4 & 12.7 & 10.7 & 10.1 & 9.4 \\
\hline Bonuses and rents & 0.1 & 0.1 & 0.1 & 0.1 & 0.1 & 0.1 \\
\hline Non hydrocarbons sector & 0.8 & 0.8 & 0.8 & 1.0 & 2.1 & 2.0 \\
\hline Nontax revenue excluding interest on saving funds & 0.6 & 0.5 & 0.6 & 0.6 & 0.6 & 0.7 \\
\hline Interest on saving funds & 0.2 & 0.2 & 0.3 & 0.4 & 1.4 & 1.4 \\
\hline Grants & 0.0 & 0.0 & 0.0 & 0.0 & 0.0 & 0.0 \\
\hline Total expenditure and net lending & 28.3 & 34.1 & 33.9 & 29.7 & 28.4 & 27.0 \\
\hline Current expenditure & 6.3 & 7.0 & 8.4 & 9.2 & 9.9 & 10.5 \\
\hline Wages and salaries & 1.8 & 2.2 & 2.9 & 3.2 & 3.5 & 3.9 \\
\hline Goods and services & 2.1 & 2.2 & 2.4 & 2.6 & 2.9 & 3.1 \\
\hline Interest payments & 0.2 & 0.4 & 0.6 & 0.7 & 0.5 & 0.4 \\
\hline Transfers and subsidies & 2.2 & 2.3 & 2.5 & 2.7 & 3.0 & 3.2 \\
\hline Other current expenditure & 0.0 & 0.0 & 0.0 & 0.0 & 0.0 & 0.0 \\
\hline Capital expenditure & 22.1 & 27.0 & 25.5 & 20.5 & 18.5 & 16.5 \\
\hline Net lending & 0.0 & 0.0 & 0.0 & 0.0 & 0.0 & 0.0 \\
\hline Domestic arrears payments & 0.0 & 0.0 & 0.0 & 0.0 & 0.0 & 0.0 \\
\hline Overall balance & 0.8 & -6.4 & -8.9 & -8.4 & -7.7 & -7.5 \\
\hline Total financing & -0.8 & 6.4 & 8.9 & 8.4 & 7.7 & 7.5 \\
\hline Foreign financing (net) & 3.4 & 3.2 & 1.7 & -1.9 & -2.9 & -2.8 \\
\hline Loans & 3.5 & 3.3 & 2.7 & 0.0 & 0.0 & 0.0 \\
\hline Amortization (-) & 0.0 & 0.0 & -1.0 & -1.9 & -2.9 & -2.8 \\
\hline Domestic Financing & -4.2 & 3.1 & 7.2 & 10.3 & 10.5 & 10.3 \\
\hline Change in government deposits abroad & 0.0 & 2.1 & 5.1 & 7.3 & 7.7 & 6.9 \\
\hline Other domestic financing & -4.2 & 1.0 & 2.0 & 3.0 & 2.9 & 3.4 \\
\hline Monetary sector & -17.0 & 14.1 & 15.6 & -1.8 & -4.2 & 1.0 \\
\hline Deposits at BEAC & -17.0 & 14.1 & 15.6 & -1.8 & -4.2 & 1.0 \\
\hline Net acquisition of non-financial assets ${ }^{2}$ & 0.0 & 0.0 & 0.0 & 0.0 & 0.0 & 0.0 \\
\hline Errors and omissions/financing gap & 0.0 & 0.0 & 0.0 & 0.0 & 0.0 & 0.0 \\
\hline \multicolumn{7}{|l|}{ Memorandum items: } \\
\hline Overall balance & 55.4 & -494.7 & -731.0 & -719.7 & -676.6 & -689.1 \\
\hline as percent of GDP & 0.8 & -6.4 & -8.9 & -8.4 & -7.7 & -7.5 \\
\hline Non oil primary balance ${ }^{3}$ & $-1,586.5$ & $-2,220.1$ & $-2,325.8$ & $-1,903.9$ & $-1,810.1$ & $-1,772.2$ \\
\hline percent of non-oil GDP & -53.7 & -65.9 & -61.0 & -41.7 & -35.2 & -31.5 \\
\hline Total Government Savings & 52.3 & 43.7 & 34.0 & 22.3 & 11.2 & 0.4 \\
\hline Of which: Government treasury accounts abroad & 34.1 & 28.4 & 21.6 & 13.4 & 5.4 & -1.7 \\
\hline Nominal GDP & $6,937.1$ & $7,744.6$ & $8,222.1$ & $8,597.1$ & $8,817.3$ & $9,162.7$ \\
\hline Nominal Non-oil GDP & $2,952.5$ & $3,367.5$ & $3,813.6$ & $4,568.6$ & $5,149.2$ & $5,623.9$ \\
\hline
\end{tabular}

Sources: Data provided by the Equatoguinean authorities; and staff estimates and projections.

1 The VAT $w$ as legislated in early 2005 ; previously this $w$ as a sales tax.

2 Includes all equity purchases of the government.

${ }^{3}$ Equal to the overall balance excluding grants minus hydrocarbons sector corporate income tax and non tax revenue plus hydrocarbons revenue generated in the secondary LNG, LPG and methanol production and purchase of share in hydrocarbons projects, minus interest on saving funds plus interest expenditure. 
INTERNATIONAL MONETARY FUND

REPUBLIC OF EQUATORIAL GUINEA

\section{Staff Report for the 2010 Article IV Consultation—Debt Sustainability Analysis}

Prepared by the Staff Representatives for the 2010 Consultation

with the Republic of Equatorial Guinea

Approved by Domenico Fanizza and Dhaneshwar Ghura

April 8, 2010

\section{EQUatorial Guinea—EXTERnal DebT SustainabiLity ANALYSIS}

1. Equatorial Guinea's external debt is projected to remain low and sustainable over the medium term. A debt sustainability analysis (DSA) — using the middle income country template-also demonstrates that the country's external debt would remain well below the CEMAC convergence criteria of 70 percent of GDP under all stress-test scenarios (Figure 1).

2. Notwithstanding, it is worth noting that the authorities have begun borrowing again in the context of implementing their large public investment program-a policy shift. As a result, external debt is expected to rise to about 12 percent of GDP in 2012 before resuming a declining trend. By 2015, external debt would amount to just below 6 percent of GDP (less than 1 percent of GDP in 2008, Table 1).

3. The new debt relates to a US\$2 billion credit line from the Chinese government signed in late 2006. The loans are earmarked for infrastructure, including four projects in electrification and improvements to Bata harbor. Loan terms are non-concessional, carrying an interest rate of $5 \frac{1}{2}$ percent, 5 years maturity with 2 years grace. A repayment guarantee in the form of liquid deposits at the Eximbank of China equivalent to 30 percent (minimum) of the outstanding stock of debt is required. The Chinese government is also reported to have extended an offer for a US\$380 million long-term loan for housing construction on more concessional terms (17 years maturity, 2 years grace, at 2 percent interest). Given the uncertainty regarding the latter loan, it is not included in the DSA, but would not alter the overall assessment.

4. Most of the stress-test scenarios indicate potential risks, but still-sustainable levels of external debt. All shocks are calibrated over the seven-year period 2003-09. The shorter calibration period is warranted given that the government only started to receive the fiscal revenues of the oil fields discovered in the mid- and late-nineties in 2003. Debt dynamics are most sensitive to an oil and hydrocarbon derivatives price shock, with a $\$ 20$ reduction in the oil price and a proportional reduction in derivatives prices leading to a potential tripling of the debt stock. A similar increase in debt would arise in the event that the authorities continue to accumulate debt after 2012 at the same rate (average) as they did over 2010-12. 
Figure 1. Equatorial Guinea: External Debt Sustainability: Bound Tests 1/ (External debt in percent of GDP)

Baseline scenario, growth and interest rate
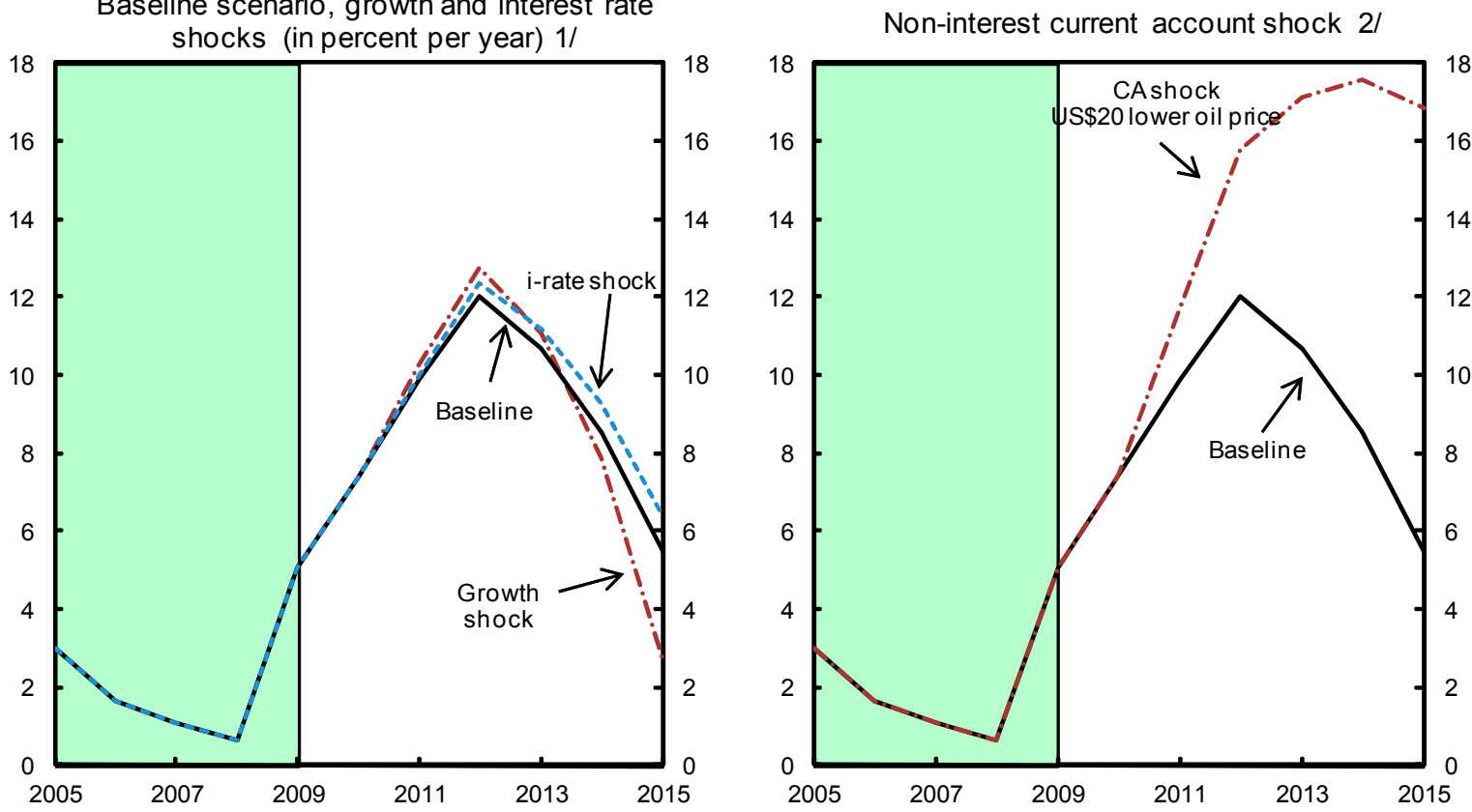

Combined and real depreciation shocks 3/
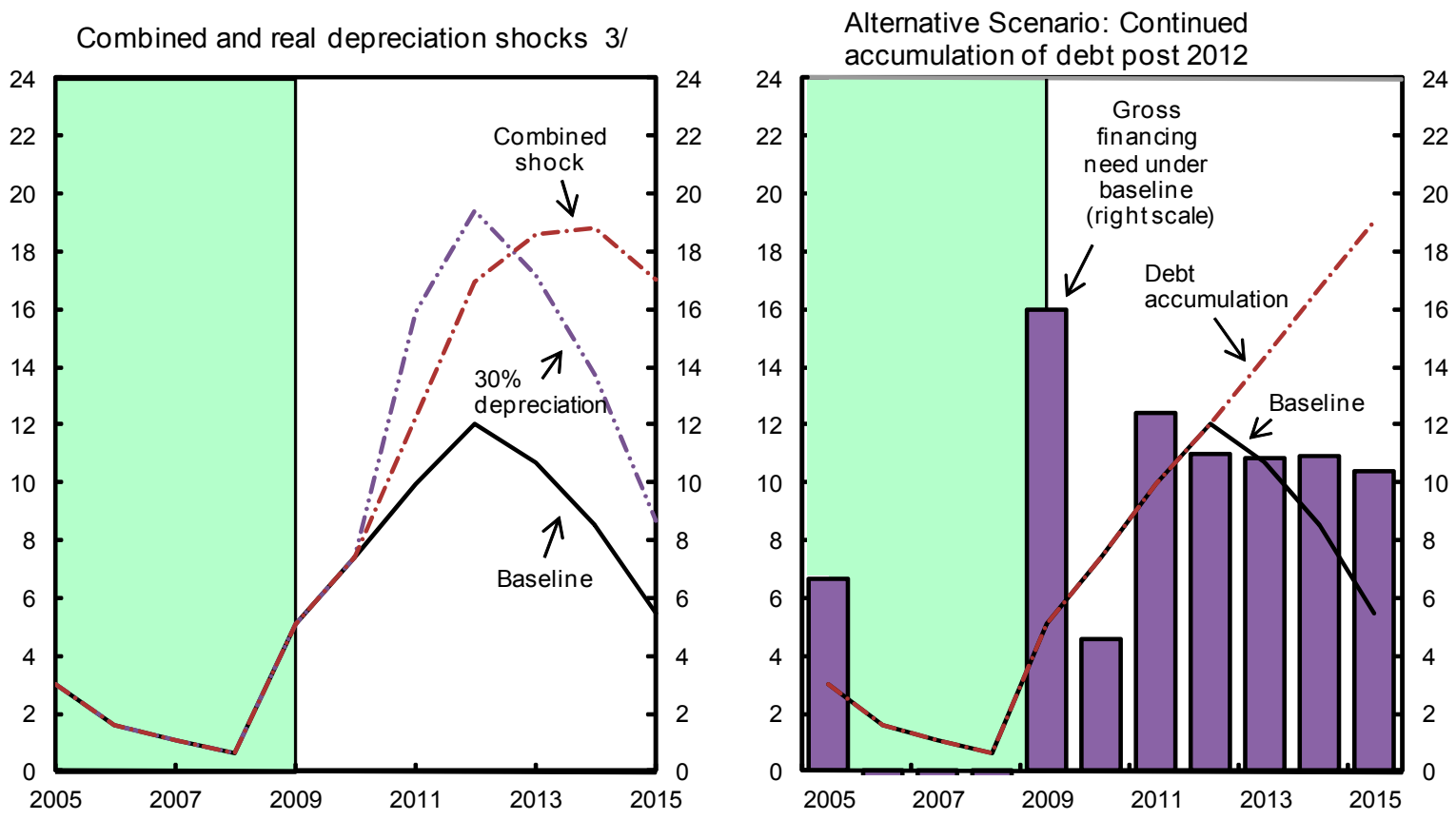

Source: International Monetary Fund, Country desk data, and staff estimates.

$1 /$ Shaded areas represent actual data. Figures in the boxes represent average projections for the respective variables in the baseline and scenario being presented. Permanent $1 / 2$ standard deviation shock applied to the growth rate. Permanent 1 standard deviation of Libor applied to the real interest rate.

$2 /$ The current account shock demonstrates the permanent effect of a US\$20 reduction in the oil price from the baseline and a proportional reduction in the price of derivatives starting in 2010.

$3 /$ One-time real depreciation of 30 percent occurs in 2010 . Combined shocks on the growth rate, real interest rate and current account. 
Table 1. Equatorial Guinea: External Debt Sustainability Framework, 2005-15

(In percent of GDP, unless otherwise indicated)

\begin{tabular}{|c|c|c|c|c|c|c|c|c|c|c|c|c|}
\hline & \multicolumn{5}{|c|}{ Actual } & \multicolumn{7}{|c|}{ Projections } \\
\hline & 2005 & 2006 & 2007 & 2008 & 2009 & 2010 & 2011 & 2012 & 2013 & 2014 & 2015 & \multirow{3}{*}{$\begin{array}{c}\text { Debt-stabilizing } \\
\text { non-interest } \\
\text { current account } 6 \\
-3.1\end{array}$} \\
\hline & & & & & & & & & & & & \\
\hline Baseline: External debt & 3.0 & 1.6 & 1.1 & 0.7 & 5.1 & 7.4 & 9.9 & 12.1 & 10.7 & 8.6 & 5.5 & \\
\hline Change in external debt & -3.2 & -1.4 & -0.5 & -0.4 & 4.4 & 2.3 & 2.5 & 2.1 & -1.4 & -2.1 & -3.1 & \\
\hline Identified external debt-creating flows $(4+8+9)$ & -18.8 & -25.6 & -18.3 & -6.3 & 5.6 & -4.2 & 3.9 & 5.2 & 4.5 & 4.4 & 4.5 & \\
\hline Current account deficit, excluding interest payments & 6.2 & -7.1 & -4.3 & -9.1 & 15.8 & 4.4 & 12.0 & 9.5 & 8.3 & 7.6 & 7.2 & \\
\hline Deficit in balance of goods and services & -43.8 & -53.7 & -51.6 & -47.3 & -12.2 & -27.8 & -20.8 & -20.1 & -20.2 & -19.8 & -18.3 & \\
\hline Exports & 87.4 & 86.8 & 81.9 & 78.8 & 69.9 & 63.2 & 60.3 & 57.1 & 53.6 & 49.7 & 46.3 & \\
\hline Imports & 43.6 & 33.1 & 30.3 & 31.6 & 57.8 & 35.3 & 39.5 & 37.0 & 33.4 & 29.9 & 28.0 & \\
\hline Net non-debt creating capital inflows (negative) & -22.8 & -18.1 & -13.6 & 3.1 & -10.7 & -8.8 & -8.3 & -4.7 & -4.1 & -3.6 & -3.1 & \\
\hline Automatic debt dynamics $1 /$ & -2.2 & -0.4 & -0.4 & -0.3 & 0.5 & 0.1 & 0.2 & 0.4 & 0.3 & 0.4 & 0.3 & \\
\hline Contribution from nominal interest rate & 0.0 & 0.0 & 0.0 & 0.0 & 0.1 & 0.2 & 0.4 & 0.6 & 0.7 & 0.5 & 0.4 & \\
\hline Contribution from real GDP growth & -0.4 & 0.0 & -0.3 & -0.1 & -0.1 & 0.0 & -0.1 & -0.1 & -0.3 & -0.1 & -0.1 & \\
\hline Contribution from price and exchange rate changes $2 /$ & -1.8 & -0.4 & -0.1 & -0.3 & 0.4 & & & & & $\ldots$ & $\ldots$ & \\
\hline Residual, incl. change in gross foreign assets (2-3) $3 /$ & 15.6 & 24.3 & 17.8 & 5.9 & -1.2 & 6.6 & -1.4 & -3.1 & -5.9 & -6.5 & -7.5 & \\
\hline External debt-to-exports ratio (in percent) & 3.4 & 1.9 & 1.3 & 0.8 & 7.2 & 11.7 & 16.4 & 21.1 & 19.9 & 17.2 & 11.8 & \\
\hline Gross external financing need (in billions of US dollars) $4 /$ & 0.5 & -0.6 & -0.5 & -1.7 & 2.0 & 0.7 & 2.1 & 2.0 & 2.1 & 2.1 & 2.1 & \\
\hline in percent of GDP & 6.7 & -6.1 & -4.0 & -9.0 & 16.0 & 4.6 & 12.4 & 11.0 & 10.8 & 10.9 & 10.4 & \\
\hline Scenario with key variables at their historical averages $5 /$ & & & & & & 7.4 & $\ldots$ & $\ldots$ & $\ldots$ & $\ldots$ & $\ldots$ & $\ldots$ \\
\hline \multicolumn{13}{|l|}{ Key Macroeconomic Assumptions Underlying Baseline } \\
\hline Real GDP growth (in percent) & 9.7 & 1.3 & 21.4 & 10.7 & 5.3 & 0.9 & 2.1 & 1.5 & 2.7 & 0.8 & 0.7 & \\
\hline GDP deflator in US dollars (change in percent) & 42.9 & 15.4 & 7.8 & 32.4 & -37.0 & 26.3 & 8.7 & 3.9 & 1.1 & 1.7 & 3.2 & \\
\hline Nominal external interest rate (in percent) & 0.7 & 0.6 & 0.9 & 0.7 & 12.3 & 4.6 & 5.4 & 5.9 & 5.7 & 4.9 & 4.6 & \\
\hline Growth of exports (US dollar terms, in percent) & 52.1 & 16.0 & 23.6 & 41.0 & -41.1 & 15.1 & 6.0 & -0.1 & -2.5 & -4.8 & -3.2 & \\
\hline Growth of imports (US dollar terms, in percent) & 24.3 & -11.3 & 19.8 & 52.7 & 21.5 & -22.1 & 24.3 & -1.2 & -6.4 & -8.2 & -2.5 & \\
\hline Current account balance, excluding interest payments & -6.2 & 7.1 & 4.3 & 9.1 & -15.8 & -4.4 & -12.0 & -9.5 & -8.3 & -7.6 & -7.2 & \\
\hline Net non-debt creating capital inflows & 22.8 & 18.1 & 13.6 & -3.1 & 10.7 & 8.8 & 8.3 & 4.7 & 4.1 & 3.6 & 3.1 & \\
\hline
\end{tabular}

$1 /$ Derived as $[r-g-\rho(1+g)+\varepsilon \alpha(1+r)](1+g+\rho+g \rho)$ times previous period debt stock, with $r=$ nominal effective interest rate on external debt; $\rho=$ change in domestic GDP deflator in US dollar terms, $\mathrm{g}=$ real GDP growth rate, $\varepsilon=$ nominal appreciation (increase in dollar value of domestic currency), and $\alpha=$ share of domestic-currency denominated debt in total external debt $2 /$ The contribution from price and exchange rate changes is defined as $[-\rho(1+g)+\varepsilon \alpha(1+r)] /(1+g+\rho+g \rho)$ times previous period debt stock. $\rho$ increases with an appreciating domestic currency $(\varepsilon>0)$ and rising inflation (based on GDP deflator).

$3 /$ For projection, line includes the impact of price and exchange rate changes. The large residuals in 2012-2015 are due to the projected reduction in government savings during that period. 4/ Defined as current account deficit, plus amortization on medium- and long-term debt, plus short-term debt at end of previous period.

5/ The key variables include real GDP growth; nominal interest rate; dollar deflator growth; and both non-interest current account and non-debt inflows in percent of GDP. Under this scenario, the debt stock turns negative starting in 2011 ( i.e., Equatorial Guinea would become a net creditor). Negative values have been suppressed.

6/ Long-run, constant balance that stabilizes the debt ratio assuming that key variables (real GDP growth, nominal interest rate, dollar deflator growth, and non-debt inflows in percent of GDP) remain at their levels of the last projection year. 
Table 2. Equatorial Guinea: External Sustainability Framework—Gross External Financing Need, 2005-15

\begin{tabular}{|c|c|c|c|c|c|c|c|c|c|c|c|}
\hline & \multicolumn{5}{|c|}{ Actual } & \multicolumn{6}{|c|}{ Projections } \\
\hline & 2005 & 2006 & 2007 & 2008 & 2009 & 2010 & 2011 & 2012 & 2013 & 2014 & 2015 \\
\hline & \multicolumn{11}{|c|}{ I. Baseline Projections } \\
\hline \multirow{3}{*}{$\begin{array}{l}\text { Gross external financing need in billions of U.S. dollars } 1 / \\
\text { in percent of GDP }\end{array}$} & 0.5 & -0.6 & -0.5 & -1.7 & 2.0 & 0.7 & 2.1 & 2.0 & 2.1 & 2.1 & 2.1 \\
\hline & 6.7 & -6.1 & -4.0 & -9.0 & 16.0 & 4.6 & 12.4 & 11.0 & 10.8 & 10.9 & 10.4 \\
\hline & \multicolumn{11}{|c|}{ II. Stress Tests } \\
\hline \multicolumn{12}{|l|}{ Gross external financing need in billions of U.S. dollars $2 /$} \\
\hline \multicolumn{12}{|l|}{ A. Alternative Scenarios } \\
\hline A1. Key variables are at their historical averages in $2010-153 /$ & & & & & & 0.7 & 1.7 & 1.7 & 0.8 & & \\
\hline A2. Continued accumulation of debt post 2012 & & & & & & 0.7 & 2.1 & 2.0 & 2.1 & 2.1 & 2.1 \\
\hline \multicolumn{12}{|l|}{ B. Bound Tests } \\
\hline B1. Nominal interest rate is at baseline plus one standard deviation of Libo & & & & & & 0.7 & 2.2 & 2.0 & 2.1 & 2.2 & 2.2 \\
\hline B2. Real GDP growth is at baseline minus one-half standard deviations & & & & & & 0.7 & 2.0 & 1.8 & 1.7 & 1.6 & 1.3 \\
\hline B3. Oil price US $\$ 20$ lower than under baseline starting in 2010 4/ & & & & & & 0.7 & 2.5 & 2.4 & 2.8 & 3.2 & 3.8 \\
\hline B4. Combination of B1-B3 & & & & & & 0.7 & 2.3 & 2.2 & 2.4 & 2.7 & 2.9 \\
\hline B5. One time 30 percent real depreciation in 2011 & & & & & & 0.7 & 2.1 & 2.0 & 2.0 & 2.1 & 2.1 \\
\hline \multicolumn{12}{|l|}{ Gross external financing need in percent of GDP $2 /$} \\
\hline \multicolumn{12}{|l|}{ A. Alternative Scenarios } \\
\hline A1. Key variables are at their historical averages in $2010-153 /$ & & & & & & 4.6 & 8.2 & 6.4 & 2.3 & & $\ldots$ \\
\hline A2. Continued accumulation of debt post 2012 & & & & & & 4.6 & 12.4 & 11.0 & 10.8 & 10.9 & 10.4 \\
\hline \multicolumn{12}{|l|}{ B. Bound Tests } \\
\hline B1. Nominal interest rate is at baseline plus one standard deviation of Libo & & & & & & 4.6 & 12.5 & 11.2 & 11.1 & 11.4 & 11.0 \\
\hline B2. Real GDP growth is at baseline minus one-half standard deviations & & & & & & 4.6 & 12.4 & 11.1 & 11.0 & 10.8 & 9.0 \\
\hline B3. Oil price US $\$ 20$ lower than under baseline starting in 2010 4/ & & & & & & 4.6 & 14.3 & 13.3 & 14.9 & 16.7 & 18.9 \\
\hline B4. Combination of B1-B3 & & & & & & 4.6 & 14.4 & 13.7 & 15.5 & 17.6 & 19.4 \\
\hline B5. One time 30 percent real depreciation in 2011 & & & & & & 4.6 & 20.3 & 18.0 & 17.7 & 17.8 & 16.9 \\
\hline
\end{tabular}

1/ Defined as non-interest current account deficit, plus interest and amortization on medium- and long-term debt, plus short-term debt at end of previous period.

2/ Gross external financing under the stress-test scenarios is derived by assuming the same ratio of short-term to total debt as in the baseline scenario and the same average

maturity on medium- and long term debt. Interest expenditures are derived by applying the respective interest rate to the previous period debt stock under each alternative scenario.

3/ The key variables include real GDP growth; nominal interest rate; dollar deflator growth; and both non-interest current account and non-debt inflows in percent of GDP. Under this

scenario, the gross external finance turns negative starting in 2014. Negative values have been suppressed.

4/ The current account shock demonstrates the permanent effect of a US $\$ 20$ reduction in the oil price and a proportional reduction in the price of the derivatives starting in 2010. 


\section{INTERNATIONAL MONETARY FUND \\ REPUBLIC OF EQUATORIAL GUINEA \\ Staff Report for the 2010 Article IV Consultation-Informational Annex}

Prepared by the Staff Representatives for the 2010 Consultation

with the Republic of Equatorial Guinea

Approved by Domenico Fanizza and Dhaneshwar Ghura

April 8, 2010

Contents

Page

Annexes

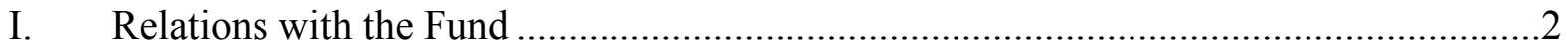

II. Relations with the World Bank Group..........................................................................5

III. Statistical Issues ........................................................................................ 


\begin{abstract}
ANNEX I.
EQUATORIAL GUINEA-RELATIONS WITH THE FUND

(as of February 28, 2010)
\end{abstract}

I. Membership Status: Joined 12/22/69; Article VIII

II. General Resources Account:

Quota

Fund holdings of currency

Reserve Position

III. SDR Department:

Net cumulative allocation

Holdings
SDR Millions

32.60

32.61

0.00

SDR Millions

31.29

25.94
Percent Quota

100.00

100.02

0.00

Percent Allocation

100.00

82.89

IV. Outstanding Purchases and Loans: None

V. Latest Financial Arrangements:

$\begin{array}{lcccc}\text { Type } & \begin{array}{c}\text { Approval } \\ \text { Date }\end{array} & \begin{array}{c}\text { Expiration } \\ \text { Date }\end{array} & \begin{array}{c}\text { Amount } \\ \text { Approved } \\ \text { (SDR Millions) }\end{array} & \begin{array}{c}\text { Amount } \\ \text { Drawn }\end{array} \\ & & & 12.88 & 4.60 \\ \text { ECF (formerly PRGF) } & 02 / 03 / 1993 & 02 / 02 / 1996 & 12.88 & 9.20 \\ \text { SAF } & 12 / 07 / 1988 & 12 / 06 / 1991 & 9.20 & 5.40 \\ \text { Stand-by } & 06 / 28 / 1985 & 06 / 27 / 1986 & \end{array}$

VI. Projected Payments to the Fund

(SDR millions; based on existing use of resources and present holdings of SDRs):

\begin{tabular}{lccccr}
\hline & \multicolumn{5}{c}{ Forthcoming } \\
\cline { 2 - 6 } & 2010 & 2011 & 2012 & 2013 & 2014 \\
\hline Principal & & & & & \\
Charges/Interest & 0.01 & 0.02 & 0.02 & 0.02 & 0.02 \\
Total & 0.01 & 0.02 & 0.02 & 0.02 & 0.02 \\
\hline
\end{tabular}

VII. Implementation of HIPC Initiative: Not Applicable

VIII. Implementation of Multilateral Debt Relief Initiative (MDRI): Not Applicable 


\section{Exchange Rate Arrangement and Safeguard Assessments}

The Bank of the Central African States (BEAC) is the regional central bank of the Central African States, of which Equatorial Guinea is a member. The safeguards assessment completed on August 30, 2004 found that the BEAC has implemented a number of measures to strengthen its safeguards framework since an earlier 2001 safeguards assessment, but further progress needs to be made in key areas. The main

recommendations of the 2004 assessment were reported in IMF Country Report No. 05/3.

Equatorial Guinea's currency, the CFA franc, is pegged to the euro at the fixed exchange rate of CFAF 655.957 per euro.

Equatorial Guinea maintains an exchange system free of restrictions on the making of payments and transfers for current international transactions. A 2007 temporary ministerial order requires authorization of the General Directorate of Banking prior to rapid money transfers abroad by non-bank financial institutions.

\section{Article IV Consultations}

Equatorial Guinea is on the standard 12-month Article IV consultation cycle.

The last Article IV consultation with Equatorial Guinea was concluded by the Executive Board on November 3, 2008 (IMF Country Report No. 09/102).

\section{Technical Assistance}

FAD provided an 18-month technical assistance during 1992-94 to reorganize the tax department and personnel training.

FAD conducted a review of PEM and tax administration systems in 1997.

FAD conducted a diagnostic mission on key deficiencies and training needs in public finance in May 2003.

FAD conducted a diagnostic mission on modernization of public expenditure management processes and steps for reforming the system in July 2005.

STA evaluated the collection of monetary statistics and proposed steps to adopt the methodology of the 2000 Manual on Monetary and Financial Statistics in December 2002.

STA conducted a diagnostic mission on real sector statistics in July 2005.

STA conducted a diagnostic mission on government finance statistics in January 2006. 
STA conducted a follow-up mission in real sector statistics in January 2006.

A macrofiscal advisor, backstopped by AFR, and paid for by the government through a reimbursement agreement with the Fund, was in residence in Equatorial Guinea from June 2006 to early May 2007.

A public financial management advisor, backstopped by FAD, and paid for by the government through a reimbursement agreement with the Fund, was in residence in Equatorial Guinea from June 2006 to early May 2007.

STA conducted a technical assistance mission in real sector statistics in March 2007.

AFRITAC Central has conducted a technical assistance mission in national accounts statistics in 2007.

AFRITAC Central has conducted a technical assistance mission in public financial management statistics in February 2008.

AFRITAC Central has conducted a technical assistance mission in price statistics in March 2008 and June 2008.

AFRITAC Central has conducted technical assistance missions in national accounts statistics in June and July 2008.

AFRITAC Central has conducted a technical assistance mission on trade statistics in July 2008.

AFRITAC Central has conducted a technical assistance mission on budget classifications in February 2009.

Two macrofiscal advisors, backstopped by AFR, and paid for by the government through a reimbursement agreement with the Fund, were redeployed in April 2008 for a one-year period. Their contract was extended in 2009, and is expected to be renewed in April 2010 for another year.

Resident Representative: None. 
AnNeX II.

EQUATORIAL GUINEA-RELATIONS WITH THE WORLD BANK GROUP

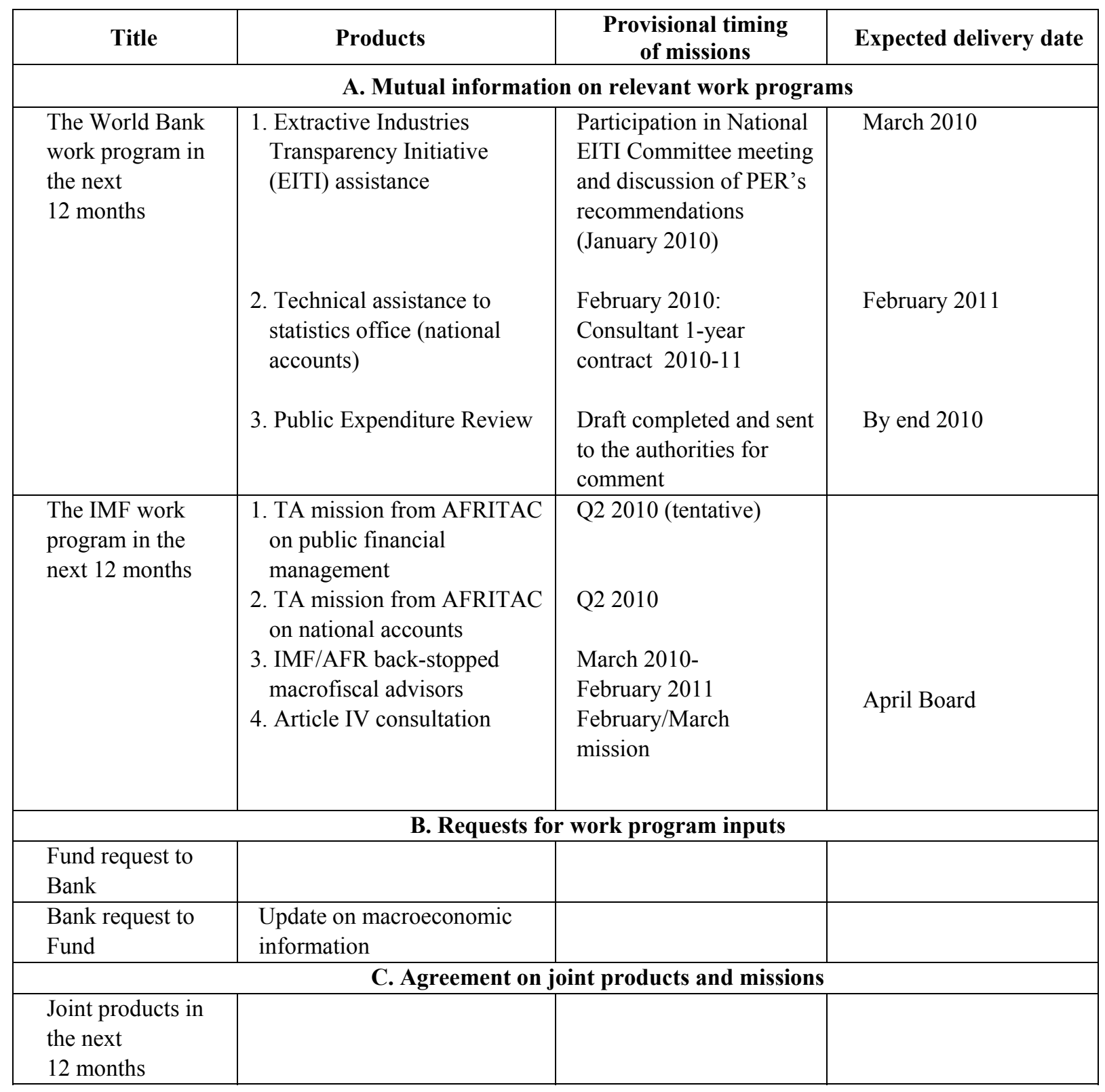




\section{ANNEX III.}

\section{EQUATORIAL GUINEA-STATISTICAL ISSUES \\ As of March 17, 2010 \\ I. Assessment of Data Adequacy for Surveillance}

General: Data provision has serious shortcomings that significantly hamper surveillance. The deficiencies in quality, timing, and coverage in most macroeconomic data are related to insufficient administrative and technical capacity. Poor centralization of information between the island and continental regions is also an issue. Technical assistance has resulted in some progress but there is still a need to consolidate these gains, including through participation in the General Data Dissemination System and significant strengthening of the capacity of the National Institute of Statistics (NIS).

National Accounts: National accounts are compiled at current and constant prices, but often contain significant inconsistencies. A 2007 STA mission provided assistance to prepare a business register/sample frame and a database on employment and compensation of employees, basic source data for improving the coverage of the national accounts. The mission revised estimates on oil and non-oil GDP for the period 2000-06 with 2000 as base year, and reclassified manufacturing of oil and gas derivatives in the non-oil sector following the $U N$ International Standard Industrial Classification of all Economic Activities (ISIC,) Rev. 3. A pilot Agricultural Production Survey (APS) 2005-06 was conducted with the support of the UN Food and Agriculture Organization, and a Quick Household Survey (QHS), with national coverage, was conducted between December 2006 and February 2007 in a sample of 5,240 households. Even though the QHS did not collect data on income and the collected expenditure data reflect seasonality, the results of the QHS, if adjusted, would have been valuable in updating the basket and weights of the CPI (currently, corresponding to 1986) and compile poverty and other social indicators. However, these data have become unavailable and are not being used. The World Bank has recently identified a resident advisor on national accounts statistics under its current service agreement, with work scheduled to begin soon. The World Bank is also assisting the government in drafting a grant proposal for a Household Expenditure Survey to be used for updating the CPI weights and compiling poverty indicators. A census scheduled for 2011 should serve to clarify long-standing misunderstandings on population statistics.

Price statistics: Compilation of the official CPI resumed in January 2009, with data collected in six major cities. However, a number of deficiencies remain, including outdated weights and composition of the basket of goods and services, and gaps in the time series corresponding to the period for which data was not collected (June 2005 - February 2006, and 2008). Imputations for missing data do not always reflect underlying trends. In general, the CPI tends to underestimate inflation.

Government finance statistics: Two macrofiscal advisors (backstopped by the IMF but paid for by the government) in place since 2008 have made progress in tracking government expenditure under the large public investment program, and following technical assistance from France, there have been some improvements in fiscal accounting. Further improvements are needed, including on coverage. Equatorial Guinea does not report fiscal data to STA for publication in International Financial Statistics and the Government Finance Statistics Yearbook. However, the authorities do provide budget execution data to AFR, although full information on the reconciliation with the monetary accounts is still lacking. The fiscal data are not subject to any internal process of verification as internal and external audit capability remains weak. There is no functional classification of expenditure, and dissemination practices needed improvement. Gains in transparency have been made through the EITI process, with reconciliation reports posted on the World Bank website in March 2010, including information on state owned oil companies. 
Monetary statistics: The BEAC regularly reports monetary, interest rates, and exchange rate statistics for publication in IFS, but delays occur in the submission of data to STA. In mid-2007 the BEAC started a project to migrate monetary statistics of member countries of the CEMAC to the methodology in the MFSM. As a part of this project, a regional workshop was organized by the BEAC in December 2007 to finalize the mapping of source data from commercial banks to the MFSM concepts and framework. STA participated in this workshop to provide guidance and advice. Submission of data by the BEAC using the standardized report forms is pending.

The accuracy of monetary statistics may be affected by large cross-border movements of BEAC-issued banknotes among Communauté Économique et Monétaire de l'Afrique Centrale (CEMAC) member countries. About 60 percent of banknotes issued in Equatorial Guinea by the BEAC national directorate circulate in Cameroon and only 26 percent remain in the country, while currency in circulation in Equatorial Guinea includes some 18 percent of banknotes from Cameroon and as much from Gabon.

Balance of payments: Although the BEAC produces balance of payments data, delays are long and the data suffer from significant inconsistencies with other datasets. At present, BOP data are often not derived from records of current stocks or flows. Statistics are still largely constructed on a historical basis from estimates rather than actual financial and customs records, including information on the hydrocarbons sector available to some parts of the government. Customs data have improved since the implementation of the Central African Customs and Economic Union reform and the deployment of customs brigades. However, data analysis is still hampered by the lack of computerization. While some progress has been made in compiling current and financial account items, the lack of current source data is a key concern.

\section{Data Standards and Quality}

Not a General Data Dissemination System participant. $\quad$ No data ROSC is available.

\section{Reporting to STA (Optional)}

Real sector statistics reported to STA (International Financial Statistics, IFS) are limited to GDP (without breakdown by sector or expenditure category), exports, and imports. The February 2010 issue of IFS includes data for GDP through 2005 and exports and imports through 2008; the latest year for which balance of payments data is available is 1996. Equatorial Guinea does not report fiscal data to STA for publication in IFS or the Government Finance Statistics Yearbook. The Banque des États de l'Afrique Centrale (BEAC) regularly reports monetary, interest rate, and exchange rate statistics for publication in IFS, but the timeliness of these data needs improvement. 


\section{Equatorial Guinea: Table of Common Indicators Required for Surveillance}

(As of March 16, 2010)

\begin{tabular}{|c|c|c|c|c|c|}
\hline & $\begin{array}{c}\text { Date of } \\
\text { Latest } \\
\text { Observation }\end{array}$ & $\begin{array}{l}\text { Date } \\
\text { Received }\end{array}$ & $\begin{array}{l}\text { Frequency } \\
\text { of } \\
\text { Data }^{7}\end{array}$ & $\begin{array}{l}\text { Frequency } \\
\text { of } \\
\text { Reporting }^{7}\end{array}$ & $\begin{array}{l}\text { Frequency } \\
\quad \text { of } \\
\text { Publication }^{7}\end{array}$ \\
\hline Exchange Rates & 03/16/10 & 03/16/10 & $\mathrm{D}$ & $\mathrm{D}$ & $\mathrm{D}$ \\
\hline $\begin{array}{l}\text { International Reserve Assets and Reserve } \\
\text { Liabilities of the Monetary Authorities }{ }^{1}\end{array}$ & Oct 2009 & $01 / 25 / 10$ & M & M & 1 \\
\hline Reserve/Base Money & Oct 2009 & $01 / 25 / 10$ & M & M & M \\
\hline Broad Money & Oct 2009 & $01 / 25 / 10$ & M & M & M \\
\hline Central Bank Balance Sheet & Oct 2009 & $01 / 25 / 10$ & M & M & M \\
\hline $\begin{array}{l}\text { Consolidated Balance Sheet of the Banking } \\
\text { System }\end{array}$ & Oct 2009 & $01 / 25 / 10$ & M & M & M \\
\hline Interest Rates ${ }^{2}$ & Oct 2009 & $02 / 26 / 10$ & $M$ & $M$ & I \\
\hline Consumer Price Index & Sept 2009 & $02 / 27 / 10$ & M & M & M \\
\hline $\begin{array}{l}\text { Revenue, Expenditure, Balance and } \\
\text { Composition of Financing }{ }^{3}-\text { General } \\
\text { Government }\end{array}$ & Dec 2009 & $02 / 24 / 10$ & M & M & I \\
\hline $\begin{array}{l}\text { Stocks of Central Government and Central } \\
\text { Government-Guaranteed Debt }{ }^{5,7}\end{array}$ & Dec 2009 & $02 / 24 / 10$ & $A$ & $A$ & I \\
\hline External Current Account Balance & Q3 2009 & $02 / 25 / 10$ & Q & Q & 1 \\
\hline Exports and Imports of Goods and Services & Q3 2009 & $02 / 25 / 10$ & Q & Q & I \\
\hline GDP/GNP & 2009 & $02 / 25 / 10$ & $A$ & A & I \\
\hline Gross External Debt & Dec 2009 & $02 / 24 / 10$ & Q & Q & I \\
\hline International Investment Position ${ }^{6}$ & & & NA & NA & NA \\
\hline
\end{tabular}

${ }_{2}^{1}$ Includes reserve assets pledged or otherwise encumbered as well as net derivative positions.

${ }^{2}$ Both market-based and officially-determined, including discount rates, money market rates, and rates on treasury bills,

notes and bonds.

${ }^{3}$ Foreign and domestic bank, nonbank financing.

${ }^{4}$ The general government consists of the central government (budgetary funds, extra budgetary funds, and social security funds) and state and local governments.

${ }^{5}$ Includes currency and maturity composition.

${ }^{6}$ Includes external gross financial asset and liability positions vis-à-vis nonresidents.

${ }^{7}$ Daily (D); weekly (W); monthly (M); quarterly (Q); annually (A); irregular (I); and not available (NA). 


\section{INTERNATIONAL MONETARY FUND}

\section{Public Information Notice}

EXTERNAL

RELATIONS

DEPARTMENT

Public Information Notice (PIN) No. 10/53

International Monetary Fund

FOR IMMEDIATE RELEASE

$70019^{\text {th }}$ Street, NW

April 23, 2010

Washington, D. C. 20431 USA

\section{IMF Executive Board Concludes 2010 Article IV Consultation with Equatorial Guinea}

On April 23, 2010, the Executive Board of the International Monetary Fund (IMF) concluded the Article IV consultation ${ }^{1}$ with Equatorial Guinea on a lapse of time basis. Under the IMF's lapse of time procedures, the Executive Board completes Article IV consultations without convening formal discussions.

\section{Background}

Despite tumbling oil prices in the wake of the global crisis and lower crude oil production following its peak in 2008, real economic activity expanded by around 5 percent in 2009, propped up by a surge in public investment and continued strong activity in hydrocarbon derivatives (mostly liquefied natural gas). Inflation edged higher, pushed up by lack of competition in the retail sector, rising public wages and strong domestic demand.

The external current account shifted into deficit, as rising hydrocarbon derivatives exports were insufficient to offset the decline in crude oil production, the plunge in oil prices and the sharp increase in public investment-related imports. The deficit was financed mostly by foreign direct investment and foreign debt.

\footnotetext{
${ }^{1}$ Under Article IV of the IMF's Articles of Agreement, the IMF holds bilateral discussions with members, usually every year. A staff team visits the country, collects economic and financial information, and discusses with officials the country's economic developments and policies. On return to headquarters, the staff prepares a report, which forms the basis for discussion by the Executive Board. At the conclusion of the discussion, the Managing Director, as Chairman of the Board, summarizes the views of Executive Directors, and this summary is transmitted to the country's authorities. An explanation of any qualifiers used in summings up can be found here: http://www.imf.org/external/np/sec/misc/qualifiers.htm.
} 
The overall fiscal balance shifted into a deficit of about 8 percent of gross domestic product (GDP), mostly because of a ramping up of investment spending as oil prices recovered. The non-oil primary balanced plummeted to a deficit of over 100 percent of non-oil GDP. The stock of government savings declined moderately but remained large, propped up in part by renewed foreign borrowing. However, the share of official foreign assets held in the Bank of Central African States (BEAC) declined significantly, with savings increasingly held offshore.

The underdeveloped financial system was unscathed by the global financial turmoil, and appears generally sound. There is no evidence of capital repatriation by foreign banks, whose local subsidiaries had no exposure to complex derivatives. Furthermore, banks remain highly liquid and report no difficulties in meeting new capital requirements.

The medium-term outlook is clouded by the onset of declining hydrocarbon production. Overall growth is likely to drop over the medium term due to lower oil output. While growth in the nonhydrocarbon sector is expected to pick up as investment in basic infrastructure begins to bear fruit and new public investments support continued construction activity, future activity will increasingly need to be driven by private sector activity. Low export diversification and high public investment-related imports will likely keep the current account in deficit over the medium term. Under current public expenditure plans, the external position would weaken, with the stock of government savings dropping sharply as oil revenues wane.

\section{Executive Board Assessment}

In concluding the 2010 Article IV consultation with Equatorial Guinea, Executive Directors endorsed staff's appraisal, as follows:

Oil has brought great wealth and growth to the Equatoguinean economy, and strong oil revenues have financed both an ambitious public investment program and the accumulation of large financial assets. Basic infrastructure is being developed, and steps have been taken toward increased transparency. However, challenges related to declining oil production and poverty are cause for concern, and the large public spending program poses significant risks to macroeconomic and external stability. Over the medium-term, oil dependence will continue, with longer-term prospects dependant on the ability to develop alternative sources of value added through economic diversification.

The public spending program must appropriately balance development needs against risks to stability. In this context, priority should be given to public investment projects aimed at improving living standards and productivity. Moving toward a sustainable fiscal position starting in 2010 would halt the expected near-depletion of the stock of government savings over the medium term. Frontloading the adjustment by bringing the non-oil primary deficit down to around 40 percent of non-oil GDP in 2010 and placing it on a downward path thereafter would both provide sufficient fiscal space for priority projects and strengthen external stability. With few near-term prospects for a sizeable increase in non-oil revenue, the bulk of the adjustment would have to come through expenditure rationalization and the right-sizing of productive investment in line with expected future economic needs. 
Improvements in public financial management are critical to ensuring the effective spending of oil wealth and strengthening macroeconomic management. In this context, investment efficiency would benefit from improved budget planning and control, redoubled efforts at prioritization, and increased use of project appraisals. The authorities should also build on recent achievements in the area of transparency and governance, including through publication of contract awards and audit reports, and increased dissemination of information on government operations, including on foreign asset holdings.

The exchange rate regime has served the country well, but continued unsustainable fiscal spending could negatively impact stability in the region. For the Central African Economic and Monetary Community (CEMAC) region as a whole, external stability requires regionally higher public savings and productivity-enhancing structural reforms to bring the real effective exchange rate in line with medium-term fundamentals. The authorities should comply with their obligations under CEMAC, raising contributions to the common pool of reserves.

Overexposure to oil and risky assets should be avoided, as should contractual debt obligations which are not warranted on financial grounds.

The wide-ranging goals of the National Development Plan necessitate a comprehensive approach to development and poverty alleviation, and increasing attention should be placed on actions to strengthen human capital and improve the business climate. Efforts to broaden and deepen financial intermediation, including lending to small and medium enterprises, should continue. Moreover, removal of barriers to private sector activity and reducing regulatory discretion are crucial steps which would allow lagged growth effects from infrastructure investment to play out more fully.

Data deficiencies hamper assessment of economic developments and policy formulation. The planned 2011 Census should resolve longstanding discrepancies on population figures, and should be complemented by a household expenditure survey which could inform future social policies. Capacity building through technical assistance should continue, with the aim of participating in General Data Dissemination System as improvements are made.

Public Information Notices (PINs) form part of the IMF's efforts to promote transparency of the IMF's views and analysis of economic developments and policies. With the consent of the country (or countries) concerned, PINs are issued after Executive Board discussions of Article IV consultations with member countries, of its surveillance of developments at the regional level, of post-program monitoring, and of ex post assessments of member countries with longer-term program engagements. PINs are also issued after Executive Board discussions of general policy matters, unless otherwise decided by the Executive Board in a particular case. 
Equatorial Guinea: Selected Economic and Financial Indicators, 2006-10

\begin{tabular}{|c|c|c|c|c|c|}
\hline & 2006 & 2007 & 2008 & $\begin{array}{l}2009 \\
\text { Prel. }\end{array}$ & $\begin{array}{l}2010 \\
\text { Proj. }\end{array}$ \\
\hline & \multicolumn{5}{|c|}{ (Annual percentage change, unless otherwise specified) } \\
\hline \multicolumn{6}{|l|}{ Production, prices, and money } \\
\hline Real GDP & 1.3 & 21.4 & 10.7 & 5.3 & 0.9 \\
\hline Oil and gas GDP (excluding hydrocarbons secondary production) & -6.4 & 11.9 & 7.1 & -6.6 & -6.3 \\
\hline Non-oil GDP (including hydrocarbons secondary production) & 29.8 & 47.2 & 18.1 & 27.6 & 10.8 \\
\hline Hydrocarbons production (thousands of boe per day) & 382.0 & 459.8 & 488.6 & 461.9 & 434.5 \\
\hline Oil and gas primary production ${ }^{1}$ & 344.8 & 356.8 & 358.3 & 318.7 & 292.1 \\
\hline Hydrocarbons secondary production $^{2}$ & 37.3 & 103.0 & 130.3 & 143.2 & 142.4 \\
\hline Consumer prices (end of period) & 3.8 & 3.7 & 6.2 & 7.7 & 6.9 \\
\hline Broad money & 14.1 & 41.3 & 30.1 & 31.3 & 13.5 \\
\hline & \multicolumn{5}{|c|}{ (Percent of GDP, unless otherwise specified) } \\
\hline \multicolumn{6}{|l|}{ Government Operations } \\
\hline Overall balance after grants (cash basis) & 23.4 & 19.2 & 15.4 & -8.0 & 0.8 \\
\hline \multirow[t]{2}{*}{ Non-oil primary balance (cash basis, percent of non-oil GDP) ${ }^{3}$} & -54.6 & -49.7 & -67.2 & -102.0 & -53.7 \\
\hline & \multicolumn{5}{|c|}{ (Millions of US dollars) } \\
\hline Gross official foreign assets & 5,078 & 7,579 & 8,118 & 8,463 & 9,417 \\
\hline Reserve assets at the BEAC & 3,067 & 3,846 & 4,431 & 3,146 & 4,100 \\
\hline \multirow[t]{2}{*}{ Government bank deposits abroad } & 2,011 & 3,733 & 3,686 & 5,317 & 5,317 \\
\hline & \multicolumn{5}{|c|}{ (Percent of GDP, unless otherwise specified) } \\
\hline \multicolumn{6}{|l|}{ External sector } \\
\hline Current account balance (including official transfers; deficit -) & 7.1 & 4.3 & 9.1 & -16.0 & -4.6 \\
\hline Outstanding medium- and long-term public debt & 1.5 & 1.0 & 0.7 & 4.9 & 7.4 \\
\hline Real effective exchange rate (depreciation -) & 7.8 & 5.8 & 3.5 & 4.2 & $\ldots$ \\
\hline
\end{tabular}

Sources: Data provided by the Equatoguinean authorities; and staff estimates and projections.

${ }^{1}$ Including oil and natural gas.

${ }^{2}$ Including LNG, LPG, butane, propane, and methanol.

${ }^{3}$ Excluding oil revenues, oil-related expenditures, and interest earned and paid. 